\title{
CENOZOIC SPUMELLARIAN RADIOLARIA WITH ECCENTRIC MICROSPHERE
}

\author{
Paulian Dumitrică
}

Received: 26 February 2019 / Accepted: 15 April 2019 / Published online: 25 April 2019

\begin{abstract}
The article presents 3 Cenozoic spumellarian Radiolaria families (Suttoniidae, Patulibracchiidae and Heliodiscidae) that have genera with eccentric microsphere. Ten such genera are discussed, of which four are new (Homunculodiscus, Parasuttonium, Cryptomanicula and Helioferrusa), and 19 species of which eleven are new. These genera evolved independently and in different directions, proving that there are no phylogenetic relationships between these families, and that if some structures are common they are the result of the eccentric position of the microsphere and of its migration during evolution. All species discussed are illustrated in eleven figures with photos at optical or scanning electron microscope.
\end{abstract}

Keywords: Cenozoic, spumellarian Radiolaria, eccentric microsphere, initial structures, evolution.

\section{INTRODUCTION}

Cenozoic radiolarian taxa discussed and described in this article are part of a study of internal structures of Mesozoic and Cenozoic spumellarian and entactinarian Radiolaria started about 40 years ago as basis of a more natural taxonomy. Although they are all spumellarians that start their skeletal building with a microsphere, they belong to at least 3 families: Suttoniidae Schaaf emend. Dumitrică, Patulibrachiidae Pessagno, and Heliodiscidae Haeckel emend Dumitrică, united here by having an eccentric microsphere. The family Pyloniidae Haeckel that has also an eccentric microsphere is not discussed here because it has been discussed with other occasions by Dumitrică (1988, 1989), De Wever et al. (2001), and others. The article intends to prove the taxonomic value of this eccentric microsphere, the skeletal diversity of such taxa, their evolution, if possible, and relationships with other radiolarians. A few of the taxa discussed in this article have already been published (Dumitrică, 1978, 1983; Dumitrică in De Wever et al., 2001). For a better understanding of them I add here a few other new species and genera found in the meantime.

\section{STUDIED SAMPLES}

With a few exceptions, the radiolarian specimens on whom this short article is based come from a few samples from cores extracted during Leg 21 of the Deep Sea Drilling Project (DSDP) located in southwest Pacific, as follows:

1. DSDP 21-205-7-1, 70-72 cm, South Fiji Basin, $25^{\circ} 30.99^{\prime} \mathrm{S} / 177^{\circ} 53.95^{\prime} \mathrm{E}$, water depth $4320 \mathrm{~m}$, cored interval 56-65 m, late Miocene, NN9 zone, glass rich foram nanno ooze (Burns, Andrews et al., 1973).

2. DSDP 21-206-24-5, 70-72 cm, New Caledonia Basin, $32^{\circ} 00.75^{\prime} \mathrm{S} / 165^{\circ} 27.15^{\prime} \mathrm{E}$, water depth $3196 \mathrm{~m}$, cored interval 210-219 m, foram bearing nanno ooze, Late Miocene, NN11 (Burns, Andrews et al., 1973).
3. DSDP 21-207A, 14CC, south Lord Howe Rise, $36^{\circ} 57.75^{\prime} \mathrm{S}, 165^{\circ} 26.06^{\prime} \mathrm{E}$, water depth $1389 \mathrm{~m}$, cored interval 169-178 m, upper part of the Chiphragmalithus cristatus nannoplankton Zone, Middle Eocene, Porangan stage (Burns, Andrews et al., 1973).

4. DSDP 21-207A, 15CC, same location and age as above, cored interval 178-187 m.

5. DSDP 21-208-30CC, southwestern Pacific, north Lord Howe Rise, $26^{\circ} 06.61^{\prime} \mathrm{S}, 161^{\circ} 13.27^{\prime} \mathrm{E}$, water depth 1545 $\mathrm{m}$, cored interval 548-557 m, early Paleocene, Prinsius martini nannoplankton Zone (Burns, Andrews et al., 1973).

6. DSDP 21-208-31CC, same hole, cored interval 558567 m, early Paleocene, Chiasmolithus danicus nannoplankton Zone (Burns, Andrews et al., 1973).

7. DSDP 21-208-32CC, same hole, cored interval: 567$576 \mathrm{~m}$, same age, but the base of the Chiasmolithus danicus zone (Burns, Andrews et al., 1973).

8. 83-481, sect. II, $73-75 \mathrm{~cm}$, Quaternary, sample from core taken by R/V Ocean Researcher 1 from the Pacific area around Taiwan, exact location not given. Sample provided by Dr. Kuei-Yu Yeh in 1998 (for detail see Cheng \& Yeh, 1989; Yeh \& Cheng, 1990).

9. PROA 96P, 241-243 cm: $5^{\circ} 12^{\prime} \mathrm{N} / 177^{\circ} 43^{\prime} \mathrm{E}$; water depth 5,828 m. The age, according to Sanfilippo \& Riedel (1970, p. 448) is late Middle Miocene, bottom of Diartus pettersoni Zone. The sample was provided by W.R. Riedel about 40 years ago.

10. DODO $123 \mathrm{D}, 10^{\circ} 25^{\prime} \mathrm{S} / 63^{\circ} 15^{\prime} \mathrm{E}$, depth $3,115 \mathrm{~m}$, Eocene, siliceous calcareous ooze. Central Indian Ocean Basin (sample provided by W.R. Riedel about 40 years ago, see Riedel, 1971).

11. Sample 1315. Radiolarian Shale Formation, late Badenian, Middle Miocene, Păuşești Otăsău village, 
Tilvici valley, Getic Depression, Romania (see Dumitrică, 2016 for location). The sample, collected in 1966 is from the upper half of the formation and consists of a bed about $5 \mathrm{~cm}$ thick of indurated yellow marl full of large and very well preserved specimens of Centrocubus cladostylus Haeckel, Lychnosphaera regina Haeckel, and Diplospongus dendrophorus Mast (Dumitrică, 1983) and with a phaeodarian fauna (Dumitrică, 1965, 2016). This bed was later found also in the locality Ocnele Mari (sample OM 54), in the same Getic Depression. As mentioned in a recent paper (Dumitrică, 2016) both exposures are unrecognizable at present; the former has been in 1967 covered by a landslide and the latter was unrecognizable about 15 years ago, when I revisited it, being completely covered by soil.

\section{TAXONOMY}

The holotypes of all the new species described in this article will be stored in the Musée Cantonal de Géologie Lausanne (MGL).

Class Radiolaria Müller, 1858

Subclass Polycystina Ehrenberg, 1838, emend. Riedel, 1967

Order Spumellaria Ehrenberg, 1875

Family Suttoniidae Schaaf, emend. Dumitrică 1983, reemended herein

Type genus. Suttonium Schaaf, 1976, emend. Dumitrică, 1983

Emended diagnosis. Bilaterally symmetrical spumellarians with initial skeleton consisting of an eccentric microsphere with or without primary rays and a crescentshaped deuteroconcha. Skeleton thin made usually of 2 parallel cortical lattice plates interconnected by short bars. Rays, when present, surrounded by a cortical shell forming three arms in the most evolved members.

Discussion. Before discussing the taxonomy of this family it is necessary a short history of the evolution of its meaning and its skeletal peculiarity.

The family Suttoniidae was erected by Schaaf (1976) on the basis of a peculiar specimen assigned to a new species and genus (Suttonium praedicator Schaaf) found in the Quaternary sediments from southwestern Pacific. He mentioned that this species has some similitudes with the spumellarian species Rhopalastrum ? anumalum described by Sutton (1896) from the Eocene of Barbados, but he specified that the very good preservation of the specimen of his new species "does not permit any doubt (sic!): Suttonium praedicator must be assigned to the order Nassellaria". According to him, the microsphere represents the cephalis, the second shell the thorax, and the three arms the abdomen. According also to him, the two lateral arms are developed around the primary lateral rays ( $\mathrm{Lr}$ and $\mathrm{Ll}$ ) of the initial nassellarian spicule and the antapical arm around the dorsal (D) ray. What followed has proven how imprudent is to be completely certain in the science of life, especially when knowledge is incomplete and the study is superficial.

Dumitrică (1983) in a special study of the skeleton of the 3 species known in this genus showed that Suttonium is not at all a nassellarian genus, but a special spumellarian, 40 as Sutton (1896) had suggested for the species he had described. It is a spumellarian that has the arms similar in structure to the arms of some Hagiastridae, from which it differs by the fact that in the course of its evolution the microsphere underwent a trend toward migration from the second chamber and the latter from the cortical threerayed chamber suggesting a nassellarian skeleton.

The two new genera - Homunculodiscus and Parasuttonium - described below and that belong also to the family Suttoniidae allowed a better understanding of the history of this family and of its structural morphology. At present, when we know that the hagiastrids have a special type of microsphere, which is never spherical, and a pyloniacean mode of growth in their early ontogenetical stages (Dumitrica in De Wever et al., 2001), whereas the microsphere of Suttonium and of all Suttoniidae is a simple sphere, and shell growth is simple, it is difficult to sustain such a filiation. Consequently, despite the structural similarity of arms any relationship between Suttoni$u m$ and the higumastrins is excluded.

Based on what we already know on the skeletal structure of the species of the genus Suttonium and on the structures of the new species and genera herein described we have now a general image of the initial and general structures of the members of this family.

The skeleton of the Suttoniidae consists of 2 parts: a diskshaped skeleton and a special initial structure. This initial structure consists, at its turn, of an eccentric spherical microsphere and a crescent-shaped attached chamber. By comparison with the initial stages of some foraminifers, I name this crescent-shaped second chamber deuteroconcha from the Greek deuter-, deuteron- second, secondary, and concha - shell. The side to which the deuteroconcha is attached to the microsphere is not casual. It is always attached to the side directed to the distalmost margin from the microsphere. To have an orientation of the shell of the genera with eccentric microsphere discussed in the present article, by comparison with the skeleton of Nassellaria I considered apical the part with the microsphere and antapical the part with the deuteroconcha. And because the two chambers (microsphere and deuteroconcha) are always together I prefer to name this structure diploconchal structure, from the Greek diplo - double and concha-shell. Microsphere is very small (about $13 \mu \mathrm{m}$ ) in the oldest species (Homunculodiscus nascens nov. sp.) but can arrive to about $40 \mu \mathrm{m}$ in the Quaternary species Suttonium praedicator Schaaf, when it is free from the constraints of a surrounding skeleton. The skeleton outside the diploconchal structure is usually a very flat disc formed, on both faces, by a porous cortical plate. The two faces of the disc are interconnected by short bars disposed irregularly or radially. These bars may be free or interconnected in the equatorial plane by bars parallel to the two faces. In optical view the perpendicular bars connecting the two faces appear as dark points and the horizontal bars interconnecting the perpendicular bars appear as less dark short lines. All this inner structure gives the shell a special ornamentation generally characteristic of species when looked in transmitted light.

The two new genera - Homunculodiscus Dumitrică and Parasuttonium Dumitrică obliged us to emend for the second time the diagnosis of this family to include in it not only species with 3 arms like the type genus but also 
genera with disc-shaped shell with or without arms because they have also an eccentric microsphere and a deuteroconcha

Range. Lower Paleocene to Recent and, generally, sparse.

Genus Homunculodiscus nov. gen.

Type species. Stylodictya tainemplekta Caulet, 1991.

Diagnosis. Test circular disc-shaped and very thin consisting of two parallel porous plates interconnected by short bars perpendicular to plates, most of them interconnected also in the equatorial plane of the disc by bars forming characteristic curved structures well visible in transmitted light. Pores circular, disposed commonly in radial rows and increasing slightly in diameter from the centre to periphery. Microsphere without primary radial spines. Deuteroconcha tending to reduce the lobes from three to one.

Remarks. This new genus differs from Stylodictya Ehrenberg, to which the type species was originally assigned (Caulet, 1991), by having an eccentric microsphere, a diploconchal initial structure, no primary radial spines, and a different shell structure.

The diploconchal structure, and especially the deuteroconcha of this genus, shows a rapid and interesting evolution. In the earliest species (Homunculodiscus nascens nov. sp., Fig. 1, very early Paleocene) this chamber is very small and divided into 3 very small globular chambers. At younger levels of the early Paleocene (Figs. 2 and 3 ) this chamber is better individualized and the number of chambers starts reducing. At last, in the middle Eocene species Homunculodiscus tainemplecta (Caulet) (Fig. 3g and Fig. 4) this chamber is very well individualized, is larger than the microsphere and together with it makes a well characteristic body that suggests a homunculus, and that is well separated from the rest of the shell by a more or less disturbed oval circle.

Etymology. From the Latin homunculus - small man and discus - disc, due to the shape of the central shell of the type species. Masculine gender.

Range and occurrence. Lowermost Paleocene to lowermost Oligocene.

\section{Homunculodiscus nascens nov. sp.}

Figures 1a-g

Description. Shell disc-shaped, circular or subcircular, very thin and with irregular margins. Margins with very small and thin spines. Shell consists of two perforate cortical plates interconnected by irregularly or radially arranged transversal bars that look like black points in transmitted light giving the shell a punctiform ornamentation. Transversal bars free or interconnected by equatorial bars arranged in short arches of different directions. Pores circular, most of them radially distributed. Diploconchal structure consisting of a very small eccentric microsphere and a small crescent shaped deuteroconcha divided into two or three chambers much smaller than the microsphere. Microsphere with circular pores smaller than

those of the disc.

Material. Eight photographed specimens of which only 3 mounted on fig. 1.

Holotype. Figure 1a, 1b., coll. MGL 103554.
Dimensions. Diameter of microsphere $13 \mu \mathrm{m}$, of shell 173-249 $\mu \mathrm{m}$.

Etymology. From the Latin word nascens - that is giving birth, because it is the first species that started the lineage of this genus.

Remarks. This is the oldest and most frequent species of this genus in the studied samples. It differs from the younger species of the genus in having the deuteroconcha rather disorderly formed and rather small.

Range and occurrence. Lowermost Paleocene, DSDP 21208-32 CC and 31 CC, north Lord Howe Rise, southwestern Pacific.

\section{Homunculodiscus cauleti nov. sp.}

Figure 2a-h

Description. Shell disc-shaped, very thin, consisting of two parallel porous plates interconnected by short transversal bars that, in transmitted light look like black spots. They are either irregularly arranged or, most of them are aligned to form arches or incomplete ellipses around the diploconchal structure. Microsphere small, spherical. Deuteroconcha antapically disposed, usually crescentshaped. Usually there is another crescent-shaped chamber beyond it. The latter is usually part of an elliptical circle surrounding the diploconchal structure. Pores circular, densely arranged in circular or radial rows, the latter especially toward periphery. These rows may be separated by radial beams prolonged into thin short peripheral spines. Periphery irregular, frayed as if not finished.

Material. Eight specimens, of which four illustrated, in the upper lower Paleocene.

Holotype. Figures 2b, 2f, coll. MGL 103555.

Dimensions. Diameter of microsphere $14 \mu \mathrm{m}$, of shell 185-224 $\mu \mathrm{m}$.

Etymology. The species is named for Dr. Jean-Pierre Caulet who described for the first time the species that will become the type species of the genus.

Remarks. This species seems to be intermediate between Homunculodiscus nascens and H. tainemplecta (Caulet). It has better marked crescent-shaped deuteroconcha and elliptical circles around it than Homunculodiscus nascens nov. sp.

Range and occurrence. Recorded only in the upper lower Paleocene sample DSDP 21-208-30 CC, north Lord Hove Rise, southwestern Pacific.

\section{Homunculodiscus tribullatus nov. sp.}

Figure 3a-d

Description. Shell disc-shaped and very thin consisting of two parallel porous plates interconnected by numerous transversal bars, some of them interconnected by equatorial bars forming inside short arches of different orientations. Microsphere eccentric, small with circular pores separated by thin intervening bars. Deuteroconcha consisting of two spherical unequal chambers sensibly smaller than the microsphere and attached at the antapical part of the latter. Pores of disc circular, densely distributed quincuncially and radially. Connections between the two 


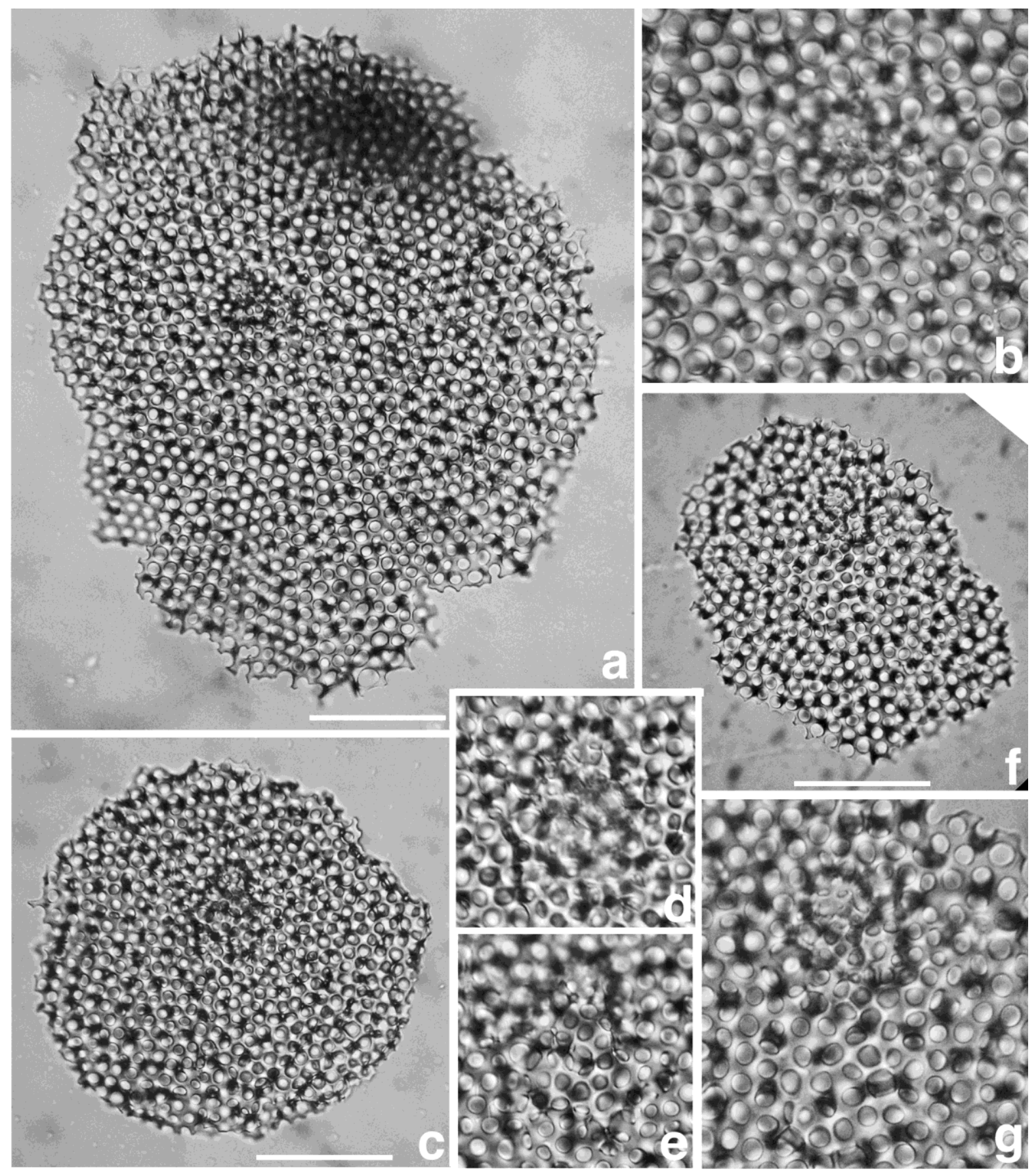

Fig. 1 a-g. Homunculodiscus nascens nov. gen., nov. sp. a-b - holotype; $\mathbf{b}$, detail, double magnification of central part of fig. a; c-e - paratype 1, d-e detail of central part, double magnification of fig. c, focused at two levels. f-g. paratype 2; $\mathbf{g}-$ double magnification of central part of fig. $\mathbf{f}$.

a, c, DSDP 21-208-32CC, early Paleocene. f, DSDP-21-208-31CC, early Paleocene. Scale bars for $\mathbf{a}, \mathbf{b}, \mathbf{c}, \mathbf{f}=50 \mu \mathrm{m}$.

porous plates by transversal bars distributed irregularly and, in places, in short arches. Periphery irregular, frayed, with short thin spines representing prolongations of the inner radial structures.

Material. Two specimens in upper lower Paleocene, DSDP 21-208-30 CC.

Holotype. Fig. 3a, c, coll. MGL 103556.

Dimensions. Diameter of shell 133-190 $\mu \mathrm{m}$, of microsphere $17-18 \mu \mathrm{m}$.

Etymology. In Latin from having 3 balls (bulla) (microsphere and two of the deuteroconcha).

Remarks. Presence of the two practically similar specimens in the type sample suggests that they are not varia- tion of the other two Paleocene species but an independent species resulted from the evolution of the Homunculodiscus nascens $\mathrm{n}$. sp. This species differs from $H$. nascens nov. sp and $H$. cauleti nov. sp. by the two spherical and well-defined chambers of deuteroconcha.

Range and occurrence. Upper lower Paleocene, DSDP 21-208-30 CC, north Lord Howe Rise, southwestern Pacific.

Homunculodiscus tainemplecta (Caulet, 1991) Figure 3e, 3g; Figure 4a-d.

1991 Stylodictya tainemplekta n. sp. - Caulet, p. 533, pl. 1, figs. 8, 9. 

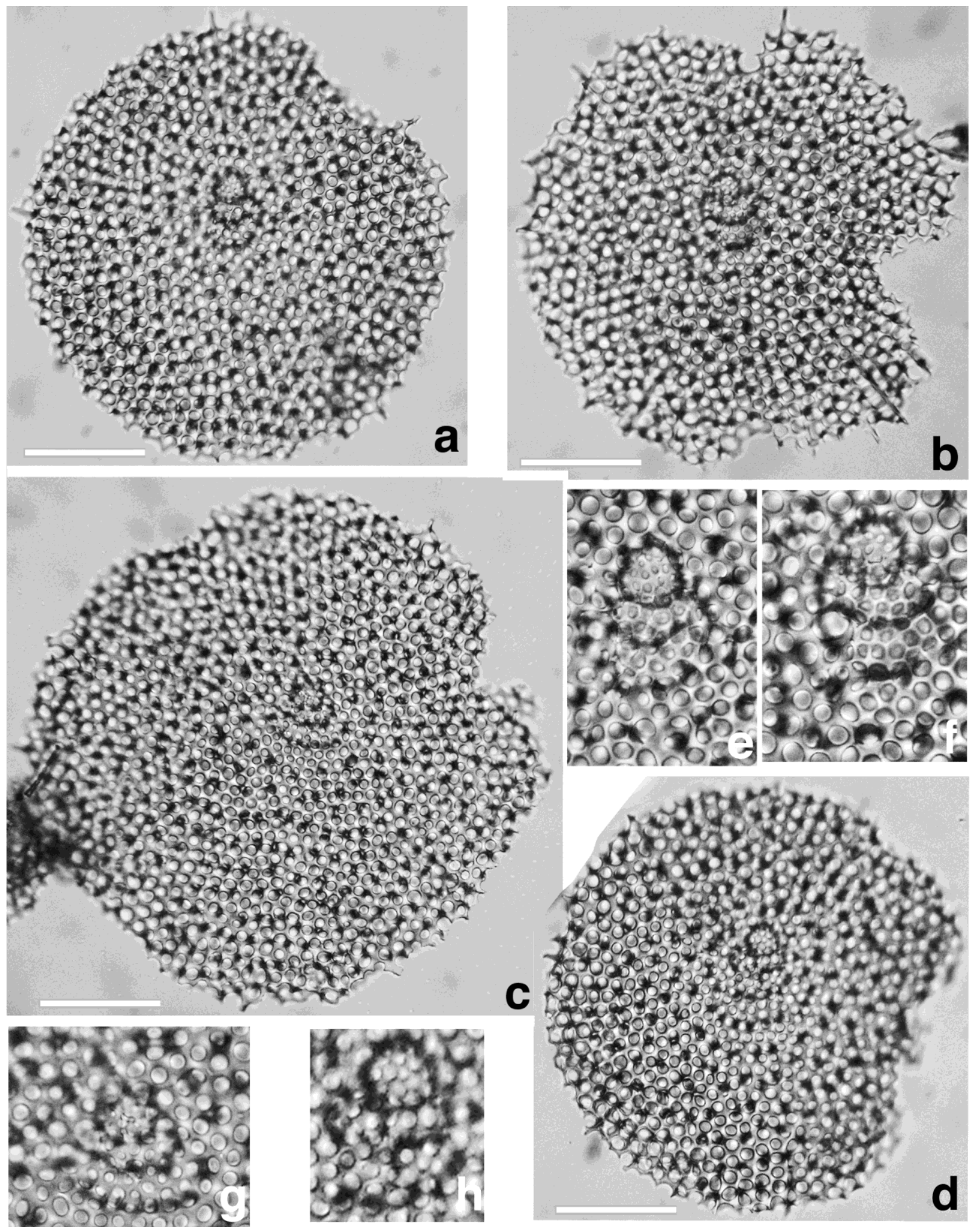

Fig. 2 a-h. Homunculodiscus cauleti nov. gen., nov. sp., DSDP 21-208-30CC; scale bars of figs. a-d = 50 $\mu$ m, of figs. e-h same bars $=25 \mu \mathrm{m}$. e represents the central part of $\mathbf{a} ; \mathbf{f}$ represents the central part of $\mathbf{b} ; \mathbf{g}$ represents the central part of $\mathbf{c} ; \mathbf{h}$ represents the central part of $\mathbf{d}$.

2005 Stylodictya tainemplecta Caulet. - Funakawa \& Nishi, p. 218.

2015 Stylodictya tainemplekta Caulet. - Kamikuri, p. 148, pl. 18, fig. 6 .

Description. Shell flat, very thin and circular, consisting of two perforated parallel cortical plates interconnected by very short bars perpendicular to the disc which, at their turn, are interconnected inside shell by bars in equatorial plane parallel to the disc forming a special inner ornamentation in optical view. Microsphere eccentric with very small and equal circular pores. Deuteroconcha larger than the microsphere, crescent-shaped and with pores sensibly larger than those of the microsphere. This diploconchal shell forms a characteristic homunculoid 


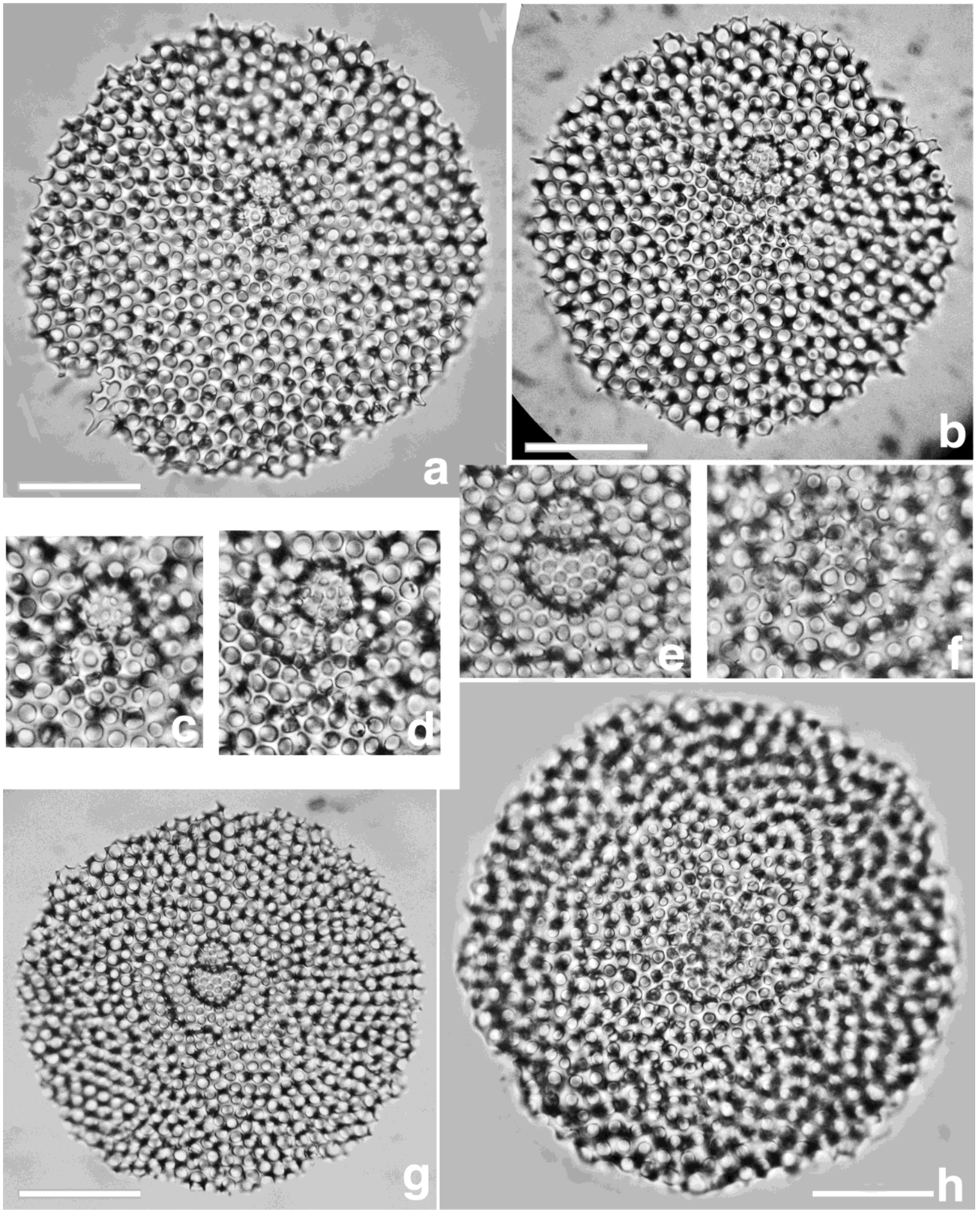

Fig. 3 a-d. Homunculodiscus tribulatus nov. gen., nov. sp., DSDP 21-208-30 CC; a, c - holotype; c - detail of central part of a double magnified. $\mathbf{b}, \mathbf{d}$ - paratype, $\mathbf{d}$ - central part of $\mathbf{b}$ double magnified. e, $\mathbf{g}$ - Homunculodiscus teinemplecta (Caulet), DSDP 21-207A-15CC; e - detail of central part of fig. $\mathbf{g}$, double magnified. Fig. $\mathbf{f}, \mathbf{h}-$ Cryptomanicula absconsa nov. gen., nov. sp. paratype; $\mathbf{f}$ - detail of surface of central part of fig. $\mathbf{h}$, focused on surface, $\mathbf{h}$ focused on middle part, DSDP 21-208-30 CC. Scale bar for entire specimens $=50 \mu \mathrm{m}$. 

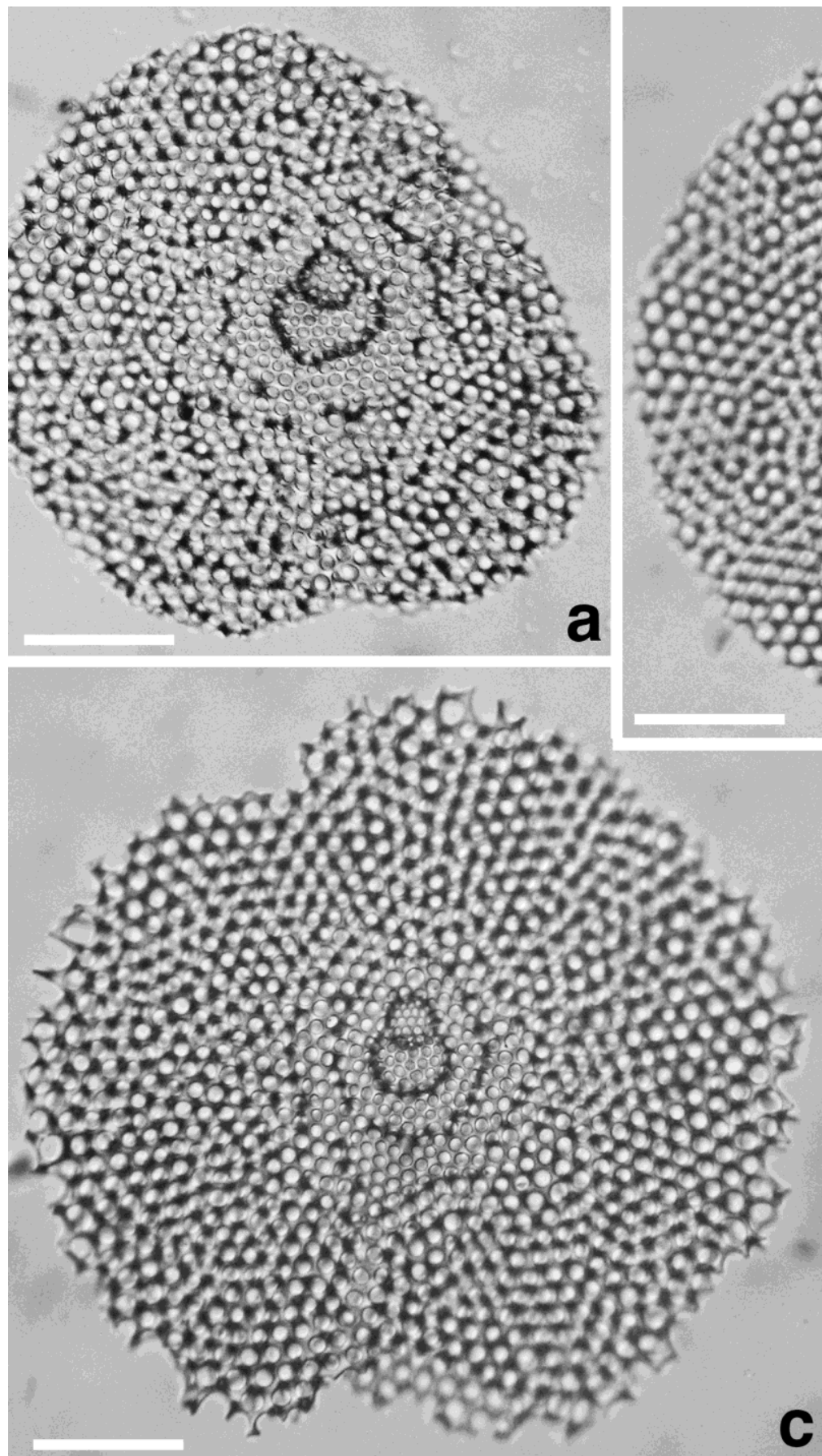

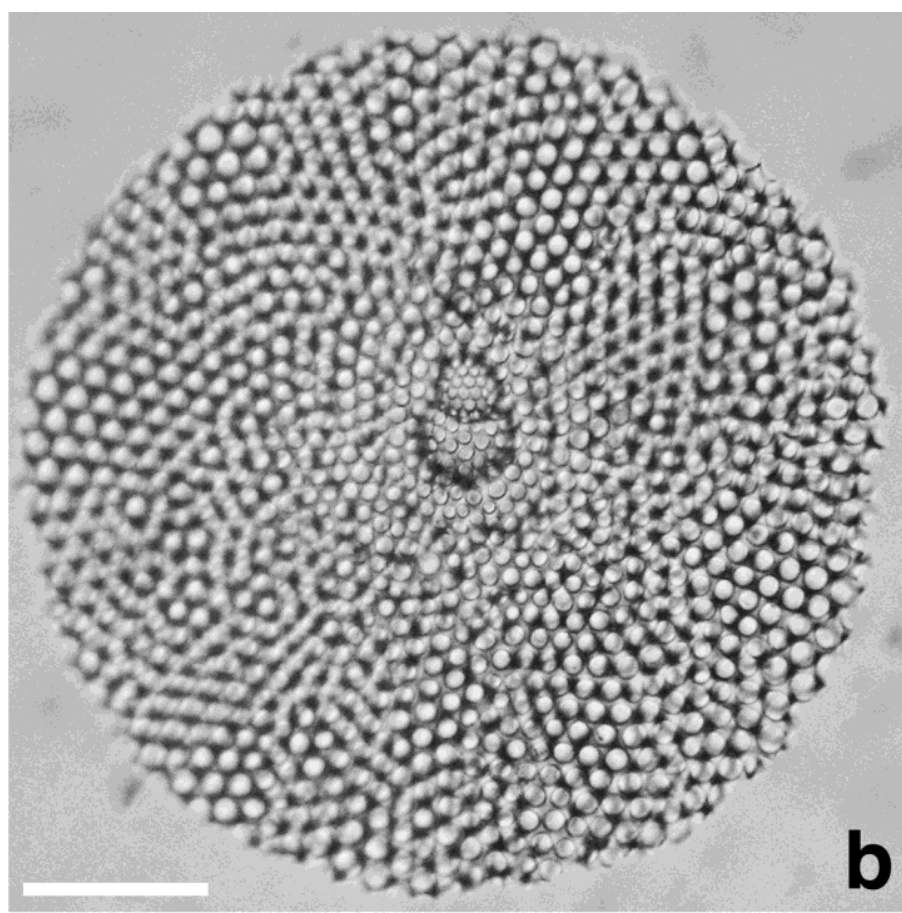

b

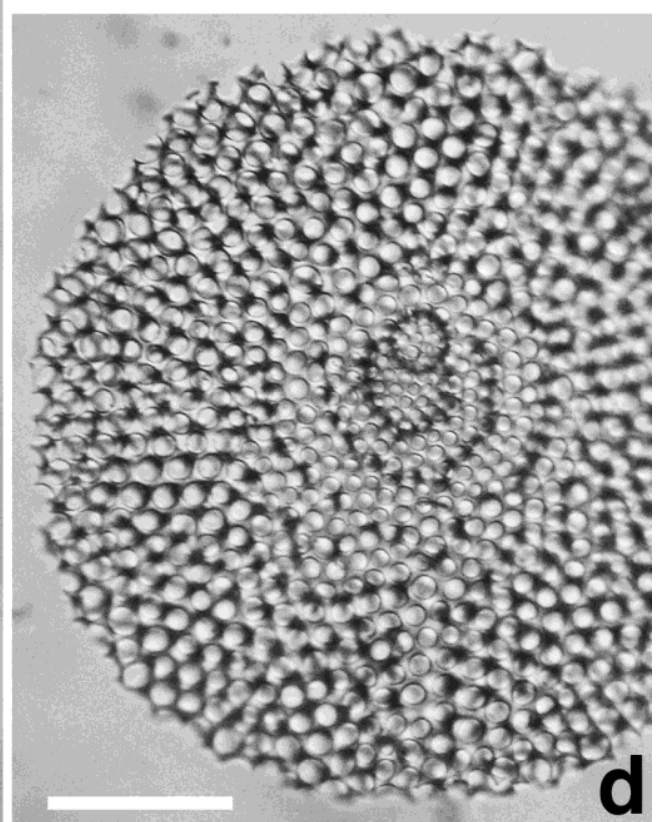

Fig. 4 a-d - Homunculodiscus tainemplecta (Caulet), DSDP 21-207A-CC. Scale bar for all figures $=50 \mu \mathrm{m}$.

structure and is surrounded by a hallow-shaped circular or oval ring. This ring may be usually surrounded, at its turn, by a second, imperfect ring. The rest of the disc has an inner structure formed either by short curved ribbons or by punctiform connections between the two plates. Pores on all shell circular, dense, increasing in size distally and radially disposed especially outside the central part.

Dimensions. Diameter of shell 165-233 $\mu \mathrm{m}$, of microsphere 13-14 $\mu \mathrm{m}$, of deuteroconcha $21-37 \mu \mathrm{m}$, of first ring around the diploconchal structure 42-46/48-56 $\mu \mathrm{m}$. Remarks. The middle Eocene specimens from Lord Howe Rise are perfectly comparable with those from Kerguelen Plateau. The stratigraphic level of the FAD of this species is unknown because in both the samples from the Kergue- len Plateau and in those from the Lord Howe Rise, there are barren intervals or sedimentation gaps between the radiolarian bearing early Paleocene and middle Eocene sediments cored in the Lord Howe Rise holes 207A and 208 of the Deep Sea Drilling Project, Leg 21. For the same reason it is impossible to know the species from whom $H$. tainemplecta originated although $H$. cauletti nov. sp. seems to be a possible candidate as mentioned under $H$. cauleti nov. sp.

Range and occurrence: Middle Eocene or earlier to early Oligocene, Kerguelen Plateau (Caulet, 1991); middle Eocene, SW Pacific, south Lord Howe Rise, DSDP21207A-14CC and 15CC; middle-late Eocene transition from western North Atlantic and Antarctic oceanic area (Maud Rise). According to Funakawa \& Nishi (2005) the 
last occurrence of this species is at $33.8-34 \mathrm{Ma}$, at the boundary between the late Eocene Eucyrtidium spinosum Zone and early Oligocene Eucyrtidium antiquum Zone in Southern Ocean (Maud Rise).

Genus Suttonium Schaaf, 1976, emend. Dumitrica, 1983a

Type species. Suttonium praedicator Schaaf, 1976

Remarks. In my article on the genus Suttonium (Dumitrica, 1983a) I had mentioned that the structure of the arms of this genus resembles perfectly the arm structure of some Cretaceous and Jurassic Hagiastridae, as for example Higumastra Baumgartner. On the basis of this similitude I had supposed that the origin of this genus should be in one of the late Cretaceous higumastrins. At present, when we know that the hagiastrid have a special type of microsphere, which is never spherical, and a pyloniacean mode of growth in their early ontogenetical stages (Dumitrica in De Wever et al., 2001), whereas the microsphere of Suttonium and of all Suttoniidae is a simple sphere, and shell growth is simple, it is difficult to sustain such a filiation. Consequently, despite the structural similarity of arms any relationship between Suttonium and the higumastrins is excluded. Until present its origin remains somehow questionable. The spherical microsphere with dense circular pores of similar size and rather regular disposition, and the crescent shape deuteroconcha attached to it on the antapical side suggest a close relationship with the genus Homunculodiscus n. gen., and especially with Homunculodiscus tainemplecta (Caulet). The presence of the three primary rays and of the arms around them seem to make this idea questionable although quite possible. If so, the three spines of this genus that constitute the centre around which the arms are built, plus the apical spine present usually on the microsphere of Suttonium and especially on the older species could have derived from 4 of the many rays lying in the equatorial plane and forming the radial structure of skeleton of $\mathrm{Ho}$ munculodiscus. In this situation, the short bars connecting the central rays of the arms of Suttonium with the cortical shell in planes perpendicular to the disc, and that form a structure resembling that of the arm of some hagiastrids, are similar to the bars perpendicular to the disc connecting the multiple rays with the two cortical plates. A good candidate for this origination is until present the specimen illustrated by Nishimura (2001, pl. 2, fig. 17) as Suttonium riedeli Dumitrică from the late Paleocene Bekoma bidartensis Zone. Certainly, this specimen does not belong to $S$. riedeli, which is a species with slender arms. Nishimura's specimen has short and very broad arms and belongs to a new, undescribed species. With this morphology Nishimura's specimen suggests that the arms of Suttonium appeared by the reduction of the two cortical plates of the disc of the genus Homunculodiscus in the interradial portions after the appearance of the three rays. This change seems to have been rather fast at geological scale, somewhere in the middle Paleocene, since the specimen illustrated by Nishimura comes from the late Paleocene and the three primitive species of Homunculodiscus herein described are early Paleocene in age.

Once appeared, the evolution of the genus Suttonium followed a migration trend of the microsphere from the deuteroconcha and of the latter from the three-rayed cortical 46 shell (Dumitrică, 1983a, p. 39-40, fig. 2). The consequence of this trend is the appearance of a nassellarian morphology having the microsphere as a cephalis, deuteroconcha as thorax and cortical shell as abdomen, and the magnification of the angle between the lateral arms from around $120^{\circ}$ in Suttonium riedeli Dumitrică to $120^{\circ}$ or greater in $S$. anomalum (Sutton) and finally to $180^{\circ}$ in $S$. praedicator Schaaf.

Range. Late or middle Paleocene to Holocene.

Suttonium riedeli Dumitrică, 1983a

1983a Suttonium riedeli Dumitrică, p. 44, pl. 3, figs. 1, 2. non Suttonium riedeli Dumitrică in Nishimura, 2001, p. 298, pl. 2, fig. 17.

Remarks. This is the oldest described species of the genus Suttonium, based on two photos provided by Dr. W. R. Riedel. This species differs from $S$. anomalum (Sutton) in the relation between the microsphere and the cortical shell, the former being almost completely included in the cortical shell. It differs also in having the antapical arm inflated on the proximal part, this inflated part being separated from the central part of shell by a constriction resulted from the presence of two opposite branches of the primary antapical ray in equatorial plane.

As discussed above, the late Paleocene specimen illustrated by Nishimura (2001, p. 298, pl. 2, fig. 17) as Suttonium riedeli does not belong to this species but represents an older new species, the oldest in fact, that makes the transition between Homunculodiscus and Suttonium. Range and occurrence. Upper Paleocene to lower Eocene; DSDP 40-11-4, 70-73 cm and DSDP 96-3-5, 42-44 $\mathrm{cm}$.

\section{Suttonium anomalum (Sutton), 1896}

Figure 6c

1896 Rhopalastrum (?) anomalum Sutton, p. 59, fig. 1.

1983a Suttonium anomalum (Sutton). - Dumitrică, p. 42, pl. 2, figs. 1-4; pl. 3, figs. 3, 4, 6-8, 11 .

2015 Suttonium anomalum (Sutton). - Kamikuri, p. 148, pl. 18 , fig. 9 .

Remarks. It seems that Schaaf (1976) was not convinced that Sutton's species is congeneric with Suttonium praedicator Schaaf because in his very short note he (Schaaf, 1976, p. 792) wrote that Sutton's species is the only species "presenting some similitudes" with his new species and genus. That is why he did not include Sutton's species in the genus Suttonium.

Range and occurrence. Upper Eocene to Pleistocene, subtropical to equatorial Pacific, and Carribean area (Barbados).

\section{Suttonium praedicator Schaaf, 1976}

Figure 6d

1976 Suttonium praedicator Schaaf, p. 789-792, pl. 1, figs. 1-5.

1983 Suttonium praedicator Schaaf. - Dumitrică, p. 42, pl. 1, figs. 1-6; pl. 2, figs. 5-8; pl. 3, figs. 9, 10, 12-15.

Remarks. $S$. praedicator is the last evolutionary species of the genus and it is interesting by having the two lateral arms perfectly opposed, and the microsphere and the apical portion of deuteroconcha out of the cortical shell.

Range and occurrence. Upper Pleistocene? to Holocene, surface sediments, southern tropical Pacific. 
Genus Parasuttonium nov. gen.

Type species. Parasuttonium taiwanense nov. sp.

Diagnosis. Test flat, three-armed, consisting of two parallel latticed plates with circular pores of rather regular size and radial or irregular disposition. Central structure consisting of a spherical and slightly eccentric latticed microsphere with 3 primary rays. Rays prolonged outside to form three latticed arms around them. Distal part of primary rays simple, not forked. Microsphere rather large, surrounded on the antapical side by a bilobate deuteroconcha.

Remarks. By its type species from the Quaternary of western Pacific around Taiwan, this genus is very close to Suttonium Schaaf by having a large latticed microsphere, a bilobed deuteroconcha on the antapical side of the microsphere and 3 radial bars originated in the microsphere: one axial and two lateral. It differs from Suttonium in not having the arms free but included in the skeletal disc, and in having the primary rays prolonged as spines outside the arms. In the three species of Suttonium the arms terminate into two curved opposite spines in planes perpendicular to the shell, one on each face, whereas this new genus has no such terminations. Moreover, in Suttonium the arms are hollow and the inner rays are connected with the wall of the arms only in perpendicular planes to the plain of the shell, whereas in P. taiwanense the spines are connected to the disc by branches in all directions.

It is strange the occurrence of Parasuttonium only in the Quaternary because its morphology is intermediate between that of Homunculodiscus (the disc-shaped skeleton) and Suttonium (three-rayed shell and a beginning of arms). With such a mixed characters, its FAD should have been somewhere in the middle or late Paleocene, before the FAD of Suttonium riedeli. Probably this enigma will be solved in future by another interpretation of its morphology or by finding much older species of this genus.

Etymology. From the Latin and Greek para - alongside, aside, closely related, and Suttonium.

Range and occurrence. Very rare in the Quaternary.

Parasuttonium taiwanense nov. sp.

Figures 6a-b

Description. Shell flat, large and thin with microsphere bearing 3 primary equidistant rays surrounded, toward the periphery of disc, by a tube and equally 3 short and wide intercallary arms without tubes or with partly formed ones. Microsphere slightly eccentric, with a bigger portion between the lateral primary rays and smaller and equal portions between lateral rays and the antapical ray. It has many densely and irregularly arranged circular pores. Deuteroconcha bilobed. Pores of shell circular, visibly larger than those of the microsphere and arranged either irregularly or in radial rows. The three primary rays thin, conical, needle-shaped, and more or less prolonged beyond the tubes into needle-shape spines. They are connected to the tube by irregularly arranged short branches. The apically prolonged tube of the holotype has also a central ray similar to the other three tubes.

Material. Two specimens, both from sample 83-481, section II, 73-75 cm of R/V Ocean Researcher 1 of National Science Council, Taiwan.
Holotype. Figure 6a, coll. MGL 103557.

Dimensions. Diameter of microsphere 20-21 $\mu \mathrm{m}$, of shell with arms $205 \mu \mathrm{m}$, of axial spine $128 \mu \mathrm{m}$, angle between the three rays about $120^{\circ}$.

Etymology. The species is named from Taiwan since it comes from sediments cored in the Pacific area around Taiwan.

Occurrence: Western Pacific around Taiwan, superficial sediments, Quaternary.

Family Patulibrachiidae Pessagno, 1971, emend Dumitrica, 2001 in De Wever et al.

Type genus. Patulibracchium Pessagno, 1971.

Remarks. In an emendation of the family Patulibracchiidae Pessagno (Dumitrica in De Wever et al. 2001, p. 142-143) based on the study of the initial skeleton, I included in this family 5 genera, of which 4 are known from early Jurassic to latest Cretaceous. The only Cenozoic genus was Trimanicula Dumitrică. According to the definition, all members of this family have 3 arms developed along the three primary rays (two lateral and one antapical) and a very small heptagonal microsphere. In this article I describe, from the early Paleocene, a new genus, Cryptomanicula n. gen., with a circular spongodiscid shaped discoidal or slightly lenticular shell, and an initial skeleton similar to that of Trimanicula, but without arms. This is the only case of armless Patulibracchiidae, which proves the priority of initial skeleton over external morphology in taxonomy. This proves also that for most Cenozoic radiolarians, which have the skeleton preserved in opal, their study in transmitted light is the best method for the knowledge of internal structure.

Genus Trimanicula Dumitrică, 1991

Type species. Trimanicula centrospina Dumitrică, 1991

Range. Early Paleocene to early Pliocene.

Trimanicula penultima Dumitrică, 1991

Figure $7 \mathrm{~b}$

1991 Trimanicula penultima Dumitrică, 1991, p. 54, pl. 3, fig. 5; pl. 4, fig. 2; pl. 8, figs. 7, 8; pl. 9, figs. 11-13.

Remarks. The species is very rare, represented until present by only the holotype. It evolved probably from the genus Patulibracchium Pessagno, its probable forerunner, by the reduction of the arms probably during the Cretaceous-Tertiary boundary crisis. Judging from the morphology of the holotype, it seems that it is a young specimen with the arms incompletely developed. This holotype differs from $T$. centrospina Dumitrică especially by the angle between the lateral primary rays that reaches $160^{\circ}$, rather close to that of some Campanian species of the genus Patulibracchium illustrated by Pessagno (1971).

Range and occurrence. Earliest Paleocene, DSDP 21208-31 CC, Lord Howe Rise, SW Pacific.

Trimanicula centrospina Dumitrică, 1991

Figures 7a, f

1972 Trigonactinium sp. - Petrushevskaya \& Kozlova, pl. 17 , fig. 2.

1987 Suttonium sp. - Petrushevskaya, p. 1451, fig. 4 (910). 

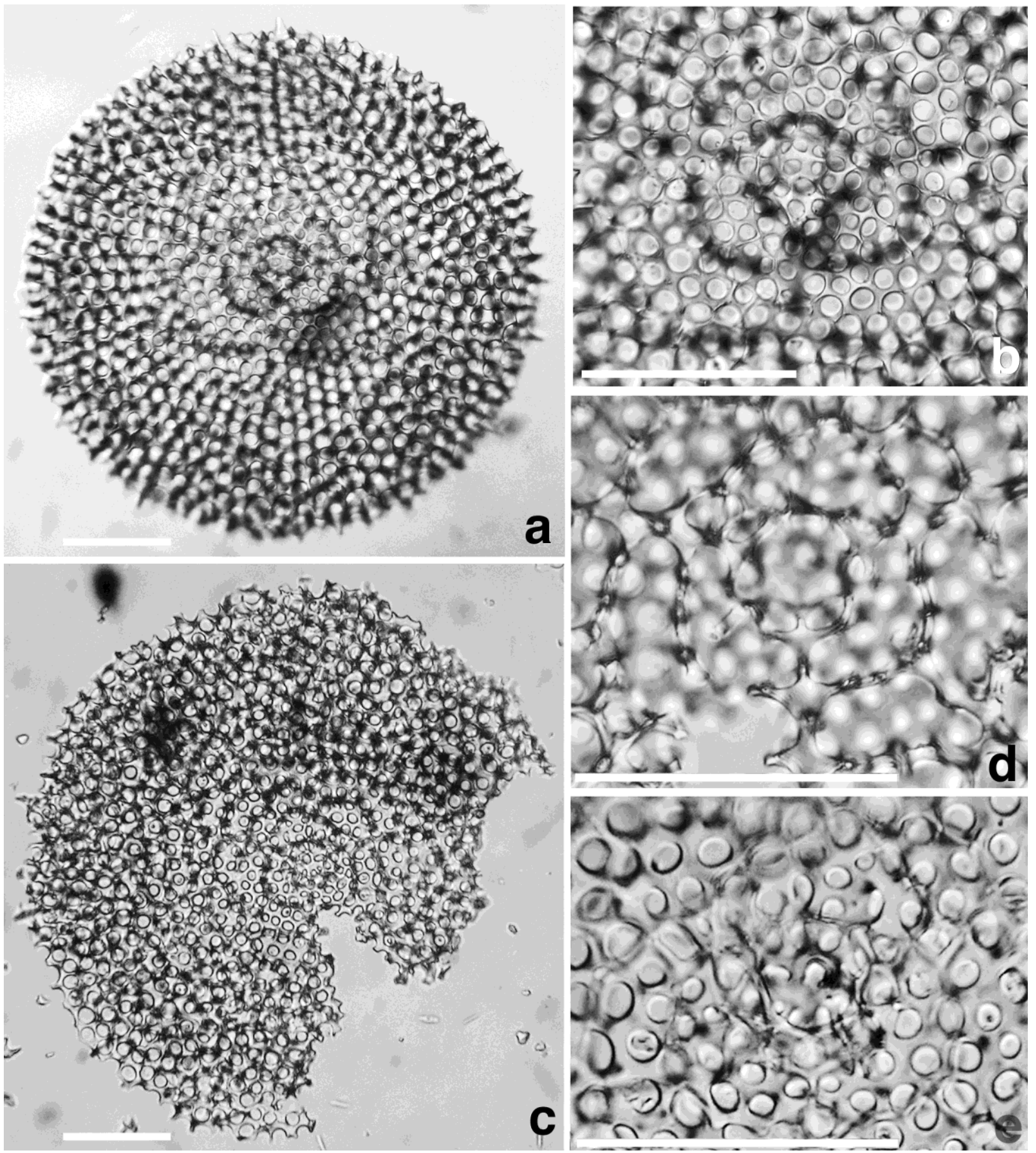

Fig. 5 a-e - Cryptomanicula absconsa nov. gen., nov. sp.; $\mathbf{a}$ - holotype, $\mathbf{b}$ - same, central part magnified. c-e - paratype with one cortical layer struck off with a razor blade: $\mathbf{c}$ - general view from the surface, $\mathbf{d}$ - same, viewed from the struck off face, focussed on primary rays; $\mathbf{e}-$ same, focussed on the 7 -sided initial ring. All scale bars $=50 \mu \mathrm{m}$

1991 Trimanicula centrospina Dumitrică, p. 52, pl. 3, fig. 4; pl. 4, figs. $1,3,4$; pl. 7, figs. 8-10; pl. 8, figs. 1-6, 9-11; pl. 9, figs. 1-10.

2001 Trimanicula centrospina Dumitrică - De Wever et al., p. 142-143, fig. 82. 1-2.

Remarks. Due to its range and regular three-rayed shell, this species evolved, directly or through a yet unknown intermediary species, from the early Paleocene species Trimanicula penultima Dumitrică by a slight migration of the microsphere towards the centre and, as a consequence, regularization of the skeleton that from bilateral- ly symmetrical and cross-shaped became regularly three radial with angles of about $120^{\circ}$ between arms.

Range and occurrence. Early Oligocene to early Pliocene so far as known.

Genus Cryptomanicula nov. gen.

Type species. Cryptomanicula absconsa nov. sp.

Diagnosis. Shell thin, lens-shaped, circular and spongy, without arms. Initial skeleton of Trimanicula type included in the centre of shell, and the three primary rays not prolonged beyond periphery of shell. Inner shell with 


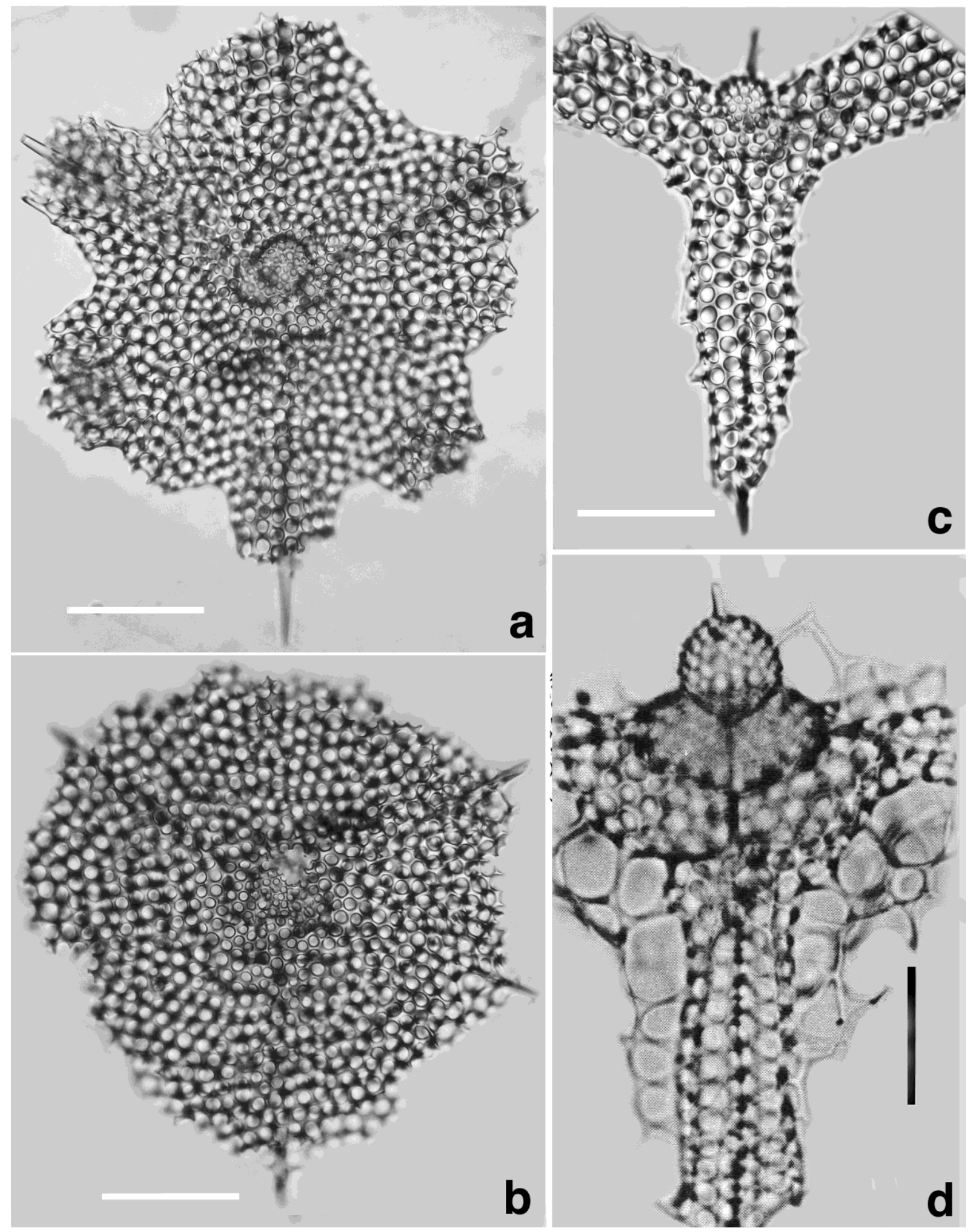

Fig. 6 a-b. Parasuttonium taiwanense nov. gen., nov. sp., Quaternary; a - holotype, $\mathbf{b}$ - paratype, incomplete specimen. $\mathbf{c}-$ Suttonium anomalum (Sutton). d-Suttonium praedicator Schaaf (from Dumitrică, 1983, pl. 1, fig. 1; pl. 3, fig. 14). Scale bars for 6a-c $=50 \mu \mathrm{m}$. 


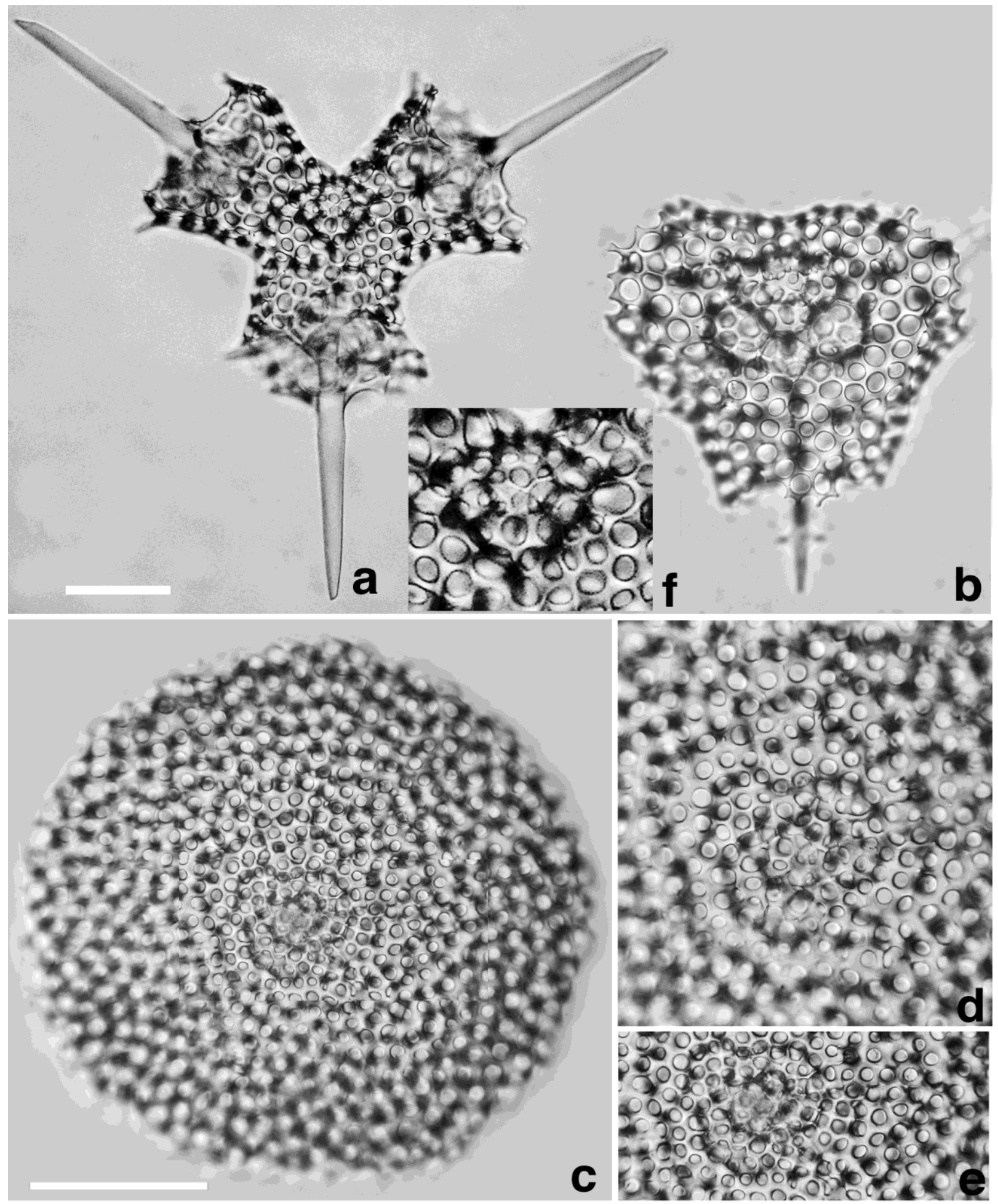

Fig. 7 a, f. Trimanicula centrospina Dumitrică, holotype rephotographed, AMPH $6 \mathrm{P}, 21-23 \mathrm{~cm}$., $\mathbf{f}-$ same, central part of a, double magnified. b. Trimanicula penultima Dumitrică, holotype rephotographed, DSDP 21-208-31 CC. c-e - Cryptomanicula absconsa Dumitrică nov. gen., nov. sp., same, paratype as that illustrated on fig. $\mathbf{3 h}$, focused at another level; d. e - detail of centre focused on surface and on microsphere, respectively, DSDP 21-208-30 CC. Scale bar of a-c $=50 \mu \mathrm{m}$.

many secondary and tertiary rays, none of them extended outside periphery of shell.

Etymology. From the Latin crypta - hidden and manicula - small hand. Feminine gender.

Remarks. By its external shape and the spongy shell, this genus resembles a spongodiscid from which it differs in having an initial skeleton of Trimanicula type as described and illustrated by Dumitrică (1991, pl. 3, figs. 4,
5; pl. 8, figs. 2, 3, 9-11). This structure is very well visible in the holotype and sectioned paratype of the type species of Cryptomanicula (Fig. 5). Its origin was probably in the species Trimanicula penultima Dumitrică, although no transitional species was until present discovered. Absence of such species is not surprizing given the extreme scarcity of the genus Trimanicula in the Paleocene. 
Range and occurrence. DSDP21-208-30CC, early Paleocene, Prinsius martini nannoplankton Zone, so far as known.

\section{Cryptomanicula absconsa nov. sp.}

Figures 3h; 5a-e; 7c

Description. Shell thin, lens-shaped with circular outline. Microsphere eccentric with 3 primary rays, of which one axial (antapical) and two lateral. Angle between lateral rays much greater than between lateral rays and the axial one. Rays not prolonged outside periphery of the disc and not visible on the surface. Besides primary rays shell contains a greater number of secondary and tertiary rays originated in the first and second extramicrospheric ring, respectively (Fig. 5c).

Material. Three specimens in the late early Paleocene sample DSDP 21-208-30 CC, Lord Howe Rise, SW Pacific. Two specimens are entire (figs. $3 \mathrm{~h} ; 4 \mathrm{a}, 4 \mathrm{~b}$ ) and one has one surface sectioned off (figs. $5 \mathrm{c}-\mathrm{e}$ ) to know the internal structure of shell.

Holotype. Specimen from Figs. 5a, 5b, coll. MGL 103558.

Dimensions. Diameter of holotype $239 \mu \mathrm{m}$, of paratype $260 \mu \mathrm{m}$, diameter of microsphere $12.5 \mu \mathrm{m}$, angle between lateral rays $150-155^{\circ}$, between lateral primary rays and axial primary ray $100-110^{\circ}$, distance between microsphere and apical border $100 \mu \mathrm{m}$, distance between microsphere and antapical border $128 \mu \mathrm{m}$.

Remarks. Perfection of the circular outline of this species suggests the possibility of the presence of other Paleocene species that could make the transition between it and Trimanicula penultima Dumitrică. The close relationship with this species is also suggested by the wide opening of the angle between the two lateral primary rays.

Etymology. From the Latin absconsus - hidden, because the initial skeleton of this species is hidden inside the lenticular disc and difficult to see.

Range and occurrence. DSDP21-208-30CC, early Paleocene, Prinsius martini nannoplankton Zone.

Family Heliodiscidae Haeckel, 1881, emend. Dumitrică, 1984

Type genus. Heliodiscus Haeckel, 1862.

Diagnosis. Test consisting of a double medullary shell with eccentric microsphere and a cortical shell that can be lenticular, spherical, discoid and simple or multiple, and connected to medullary shell by numerous beams directed to the two faces.

Remarks. Hollande \& Enjumet (1960) seem to be the first researchers who remarked the eccentric position of the microsphere in the outer medullary shell. In the Addendum of their monograph they described two new taxa: Excentrodiscus echinatus, a new genus and species with a spherical cortical shell and a double medullary shell with an eccentric microsphere, and Astrophacus viminalis, a new species with external characters of Astrophacus Haeckel, but with eccentric instead of concentric microsphere. Due to this similarity they questioned the accuracy of Haeckel's observation concerning the position of the microsphere in this genus.

Regarding Heliodiscus phacodiscus Haeckel, the type species of the type genus of the family, we have no information concerning the position of its microsphere within the outer medullary shell because the central part of the type specimen illustrated by Haeckel (1862, pl. 17, figs. 5-7) is obscured, probably due to the thickness of the cortical shell. In the specimen of the same species illustrated by Tan \& Chen (1999, fig. 5-118), as well as in other Quaternary species of this genus illustrated with drawings by them, the microsphere is also invisible. However, given its Quaternary age and the eccentric position of the microsphere in other Quaternary species of the genus Heliodiscus, we can rather confidently ascertain that it is also eccentric in the type species because the Phacodiscidae and Coccodiscidae were already extinct before the Quaternary and even the Pliocene. My assertion could be considered groundless because Haeckel (1862, pl. 28, figs. 11, 12), in his monograph on the living Radiolaria from Messina, illustrated the first coccodiscid (Coccodiscus darwinii Haeckel) and even described in detail the structure of its soft body. He wrote (Haeckel, 1862, p. 485-486) that he found the only specimen in the water from Messina and he preserved it in liqueur to study its soft body later. Knowing generally from my practice the occurrence of the Coccodiscidae and Phacodiscidae I was always intrigued by the presence of this genus and species in the living plankton and I was feeling that something is not in order with it. In my opinion, it had no place among the living plankton from Messina. I thought that Haeckel either cheated or made a mistake when he included this species in his monograph. But how could he describe in detail the soft body of this species? Imagination? I raised this problem last year during the last meeting of our group of co-authors of the Project of Catalogue of Neozoic Radiolaria, which included JeanPierre Caulet, Luis O’Dogherty, Noritoshi Suzuki and myself. I expressed my strong doubt about the presence of the species Coccodiscus darwinii in the living plankton illustrated in Haeckel monograph. I expressed my feeling that Haeckel knew the Eocene fauna from Barbados at the time when he wrote this monograph and he included this species to have one more genus in it. Noritoshi Suzuki who had worked in the "Joint Haeckel and Ehrenberg Project (2009) didn't agree with me arguing that at that time Haeckel did not had samples from Barbados. However, looking in the collection of photos he had made from Haeckel's house and collection in Jena, he fortunately found and showed us a photo of an individual slide with Haeckel's hand writing on which it was written: "Coccodiscus Darwinii Haeckel, 1862, Barbados". It was the holotype of this species. This was exactly the proof I had looked for long time, the proof that Coccodiscus darwinii was not a living species but an Eocene one as most of the coccodiscids.

A somehow similar problem could raise Heliodiscus asteriscus Haeckel. Tan \& Chen (1999, p. 208, fig. 5-121) illustrated with a drawing a specimen of this species in whose centre of the outer medullary shell they drew a darker spot suggesting probably that the microsphere is centrally disposed. If so, this drawing is certainly wrong. A photo of the same species published in Dumitrică (1978, pl. 2, fig. 4) shows clearly an eccentric microsphere represented by an eccentric dark spot. To be completely sure of the position of the microsphere I sectioned a specimen of this species according to the method I described in De Wever et al. (2001, p. 436-439). The spec- 
imen had been found in the late middle Miocene sample PROA 96P in which the microsphere was very difficult to see due to the thick cortical shell, but it became rather well visible in eccentric position after scratching out a part of this shell. Nigrini (1967, pl. 3, figs. 1a, 1b) and Kawakami (2001, pl. 1, fig. 13) illustrated also specimens of this species with well visible eccentric microsphere. This suggests that the two species (H. phacodiscus and $H$. asteriscus) are congeneric and that both belong to the genus Heliodiscus.

According to the emended definition (Dumitrică, 1984; De Wever et al., 2001) the main characteristic of this family is the presence of a double medullary shell with eccentric microsphere and of a latticed cortical shell that has various geometrical shapes: (lens, disc or sphere) and consists of a variable number of layers.

The fossil record proves that the spherical heliodiscids are the oldest members of the family. They are known from the late Santonian-early Campanian from western Kamchatka (Vishnevskaya \& Dumitrică, 2003; Vishnevskaya, 2006). The lenticular and disc-shaped heliodiscids (Heliodiscus and Excentrococcus) are known since the Miocene and they have probably their origin in horizontal gene transfers between Excentrodiscus and a phacodiscid species probably during the late Paleogene or early Miocene when the lens-shaped phacodiscids were still frequent.

Range and occurrence. The oldest representatives of the family are known in late Santonian - early Campanian from western Kamchatka Peninsula (Vishnevskaya \& Dumitrica, 2003; Vishnevskaya \& Bernard, 2004; Vishnevskaya, 2006). At this stratigraphic level the family is represented by spherical species with 3 or 4 shells belonging to the genera Excentrodiscus and probably Excentrosphaerella. Excentrosphaerella seems also to occur in the early Paleocene, represented probably by Haliomma teuria Hollis (1997). Until present no other species of this genus is known in the Cenozoic except the type species occurring in the late middle Miocene of Romania. In exchange, the genus Excentrodiscus is rather well represented by several species in the Eocene and Oligocene.

Genus Heliodiscus Haeckel, 1862

Type species. Heliodiscus phacodiscus Haeckel, 1862.

Diagnosis. Cortical test lenticular and single with a double medullary shell with eccentric microsphere.

Remarks. Morphologically Heliodiscus resembles very well the Paleogene Phacodiscidae, as for example Astrophacus Haeckel, 1881, Periphaena Ehrenberg, 1873, etc., from which it differs in having the double medullary shell with eccentric microsphere. This resemblance is probably the result of a horizontal gene transfer between a phacodiscid species and a species of Excentrodiscus, genus frequent in the Paleogene and later. It could be also the result of a convergence but I do not see how, all radiolarians being planktonic organisms.

Range. Miocene to Recent. It seems that this genus is not present in the Paleogene because no lenticular morphospecies with eccentric microsphere have been illustrated in any Paleogene species (Sanfilippo \& Riedel, 1973; Funakawa et al., 2006; Kamikuri, 2015, and others).
Heliodiscus riedeli nov. sp.

Figures 8b, e, f; 9a

Description. Shell large, disc-shaped with a small double medullary shell and a wide cortical shell. Microsphere very small, eccentric in the outer medullary shell and connected to it through a few cylindrical beams of different length. Outer medullary shell spherical or slightly prunoid with wide circular or polygonal pores separated by thin intervening bars and included in the cavity of the cortical shell to which it is connected with the two faces of this shell by a bunch of very short rays. Cortical shell flat, very thin and perforated by numerous very small polygonal pores arranged either disorderly or, partly, radially. Periphery of disc armed with numerous threebladed, short, and pyramidal spines disposed in several planes.

Material. Eight specimens in sample PROA 96P, 241$243 \mathrm{~cm}$, late middle Miocene.

Holotype. Figure 8b, coll. MGL 103559.

Dimensions. Diameter of microsphere 17-19 $\mu \mathrm{m}$, of outer medullary shell 47-54 $\mu \mathrm{m}$, of cortical shell 241-295 $\mu \mathrm{m}$.

Etymology. The species is named for William R. Riedel for his great contribution to the study of Cenozoic radiolarians. It is also in the sample provided by him that this species was found.

Remarks. This species differs from all the other species of this genus in having a large, completely flat disc-shaped cortical shell and many short pyramidal spines on periphery.

Range and occurrences. Late middle Miocene, central Pacific.

\section{Heliodiscus bipolaris $\mathrm{n} . \mathrm{sp}$}

Figures 8d, e, h

Description. Medullary test double, prunoid with an eccentric microsphere. Cortical shell ovoid in face view and lenticular in side view, the broader part at the end where the microsphere is closer to the outer medullary shell. The two ends of cortical shell with a bunch of numerous irregular and short spines. No opening visible at these ends.

Material. A single specimen in DSDP 21-206-29CC.

Holotype. The illustrated specimen, coll. MGL 103560.

Dimensions. Diameter of microsphere $14 \mu \mathrm{m}$, of outer medullary shell $40-50 \mu \mathrm{m}$, length of cortical shell 135 $\mu \mathrm{m}$, breadth of cortical shell shell $102 \mu \mathrm{m}$.

Etymology. Having two poles.

Remarks. This species differs from the other species of the genus by not having a circular outline but en elliptical one in face view and peripheral spines only at the two ends of the cortical shell.

Range and occurrence. Late Miocene, New Caledonia Basin, DSDP 21-206-29CC.

\section{Genus Helioferrusa nov. gen.}

Type species. Helioferrusa hollandei nov. gen., nov. sp. Diagnosis. Skeleton of Heliodiscus type but bearing a peripheral porous ring instead of spines. Microsphere eccentric in the outer medullary shell.

Etymology. The generic name comes from the Greek helios - Sun and Odette Ferru who illustrated the radiola- 
rian species from the monograph by Hollande \& Enjumet (1960) with wonderful drawings similar in quality to those made by Adolf Giltsch for Haeckel's 1887 monograph. Feminine gender.

Remarks. This genus resembles a Coccodiscus Haeckel from which it differs in having a double medullary shell with eccentric microsphere and originated very probably in Heliodiscus riedeli nov. sp. with which its cortical shell resembles very well and with which it co-occurs in the late middle Miocene assemblage from sample PROA 96P.

Range and occurrence. Late middle Miocene so far as known.

\section{Helioferrusa hollandei nov. sp.}

Figures 9b, c, h, i

Description. Shell thin disc-shaped consisting of 4 shells: a double medullary shell with an eccentric microsphere, a large main cortical shell, and a peripheral equatorial ring. Microsphere very small, eccentric in the outer medullary shell. Outer medullary shell prunoid or subspherical, with large circular or polygonal pores and included in the cavity of the cortical shell with whom it is connected to the two faces of the latter by a bunch of oblique radial beams. These beams do not cross this shell. Cortical shell large, disc-shaped or lenticular and a little thicker than the diameter of the outer medullary shell. It has numerous very small circular to oval pores of various sizes and irregularly or, partly, radially disposed. This shell is surrounded by a peripheral ring with similar pores but usually smaller. Inside this ring there are radial costae that divide its circumference in unequal segments. Periphery of ring with tiny thorns.

Material. Four specimens, from the late middle Miocene sample PROA 96P.

Holotype. The illustrated specimen, coll. MGL 103561.

Dimensions. Diameter of microsphere 17-19 $\mu \mathrm{m}$, of outer medullary shell $49-54 \mu \mathrm{m}$, of cortical shell 173-232 $\mu \mathrm{m}$, of peripheral ring 232-330 $\mu \mathrm{m}$.

Etymology. The species is dedicated to André Hollande, co-author of the valuable monograph on living Radiolaria from the Gulf of Alger.

Remarks. In this species I included two morphotypes: one found in sample PROA 96P (Fig. 9b), represented by 7 specimens, the other one in sample DSDP 21-205-7-1, $70-72 \mathrm{~cm}$ from South Fiji Basin, which is late Miocene (NN10 Zone) in age (Fig. 9c). These two morphotypes are practically contemporaneous but morphologically rather different. The morphotype from the sample PROA 96P has the cortical shell flat, very thin similar to that of Heliodiscus riedeli nov. sp., and the peripheral ring has thin intervening bars between pores. The morphotype from the sample DSDP 21-205-7-1, 70-72 has the lenticular cortical shell, with rather convex faces and larger pores, and the peripheral ring has much smaller pores, separated by larger intervals, approximately as large as diameter of pores. These differences seem to be rather important, at least at subspecies level, but because I found a single specimen with such characters in that sample I do not know what signification they could have.

Range and occurrence. Late middle Miocene from tropical and subtropical Pacific.
Genus Excentrodiscus Hollande \& Enjumet, 1960

Type species. Excentrodiscus echinatus Hollande \& Enjumet, 1960.

Remarks. This genus is the longest-ranged taxon of the family. I included in this article two new species from the Eocene and one from the middle Miocene.

Range and occurrence. Late Santonian or early Campanian to Recent.

\section{Excentrodiscus dodo nov. sp.}

Figures 9d, e

?2015 Excentrodiscus aff. oculatus (Ehrenberg). - Kamikuri, p. 148, pl. 15, figs. 3, 4, 6, 8 .

Description. Cortical shell small, spherical with numerous circular pores. Pores equal, hexagonally framed, rarely pentagonally framed. Intervening bars triangular in transverse section forming crests. At vertices of frames test develops very small pointed thorns that make the surface of test rough. Inside cortical shell there is a spherical double medullary shell with an eccentric microsphere. Microsphere with a few polygonal pores and connected to outer medullary shell through very thin radial beams of different length depending of their position. They stop in the wall of outer medullary shell. Outer medullary shell spherical, thin-walled with polygonally framed circular pores. This shell gives rise to many thin radial bars that connect it to cortical shell.

Material. One specimen in sample DODO 123D.

Holotype. The illustrated specimen, individual slide, stored in the MGL 103562.

Dimensions. Diameter of microsphere $18 \mu \mathrm{m}$, of outer medullary shell $55 \mu \mathrm{m}$, of cortical shell $122 \mu \mathrm{m}$.

Etymology. The species is named after the sample DODO of the Scripps Institution of Oceanography, California, in which the species was found.

Remarks. The shell of Excentrodiscus dodo resembles that of E. kamikurii nov. sp. in size and thickness of shell, but differs from it in not having spines, and in the fact that the beams connecting the microsphere with the outer medullary shell are not aligned with those connecting the latter with the cortical shell. It resembles also the middle/late Eocene specimens determined by Kamikuri (2015) as Excentrodiscus aff. oculatus (Ehrenberg) by not having long spines and by the type of cortical pores.

Range and occurrence. Middle? Eocene, DODO 123 D, Central Indian Ocean Basin.

\section{Excentrodiscus kamikurii nov. sp}

Figures 9f, g cf. 2015 Excentrodiscus aff. oculatus (Ehrenberg). - Kamikuri, p. 148, pl. 15, figs. 3, 4, 6, 8 .

Description. Microsphere very small, eccentrical, with 810 wide polygonal pores interconnected to outer medullary shell through 8-10 very thin beams of various length depending of their position in shell. Outer medullary shell spherical, rather thin and latticed with polygonally framed circular pores. Intervening bars thin, triangular in transverse section. Cortical shell spherical, rather thinwalled with numerous circular pores. Intervening bars thin with sharp crests and short and thin by-spines at vertices. Cortical shell bears 8-10 needle shaped spines about as long as skeleton ray. These spines are originated either 
in the microsphere or in the wall of the outer medullary shell, no one in the cortical shell.

Material. One specimen in sample DODO 123D.

Holotype. The illustrated specimen, individual slide, coll. MGL 103563...

Dimensions. Diameter of microsphere 16-17 $\mu \mathrm{m}$, of outer medullary shell $57 \mu \mathrm{m}$, of cortical shell $125 \mu \mathrm{m}$.

Etymology. The species is named for Dr. Shin-ichi Kamikuri, Ibaraki University, Japan, for his contribution to the knowledge of Cenozoic radiolarians and for having illustrated some specimens of Eocene Excentrodiscus.

Remarks. Shell of this species resembles the shell of the co-occurring species in sample DODO 123D from which it differs in having radial spines. It resembles very much the Recent species Excentrodiscus echinatus Hollande \& Enjumet from the Gulf of Alger in shape and size of shells from which it only differs in having a smaller number and shorter spines. The specimens illustrated by Kamikuri (2015) as Excentrodiscus aff. oculatus (Ehrenberg) are rather similar to this new species from whom they differ especially in having shorter spines.

Range and occurrence. Middle? Eocene of Indian Ocean.

Excentrodiscus grigorei nov. sp.

Figures 10a-d

?1978 Excentrodiscus sp. - Dumitrică, pl. 4, figs. 5-6.

2001 Excentrodiscus sp. - Dumitrică in De Wever et al., p. 124, Fig. 69.2, 69.5 .

2010 Excentrodiscus japonicus (Nakaseko \& Nishimura). - Kamikuri, pl. 2, figs. 13a-b, 14a-b.

Description. Cortical test spherical to slightly ovoid, thick-walled in mature stage. Pores circular or oval on the inner side of cortical shell polygonally (pentagonally or hexagonally) framed externally, with sharp crests and thin spines at vertices. Medullary shell double, with a very small eccentric and polyhedral microsphere and a slightly oval outer medullary shell. Outer medullary shell interconnected with microsphere through about 7-8 unequal beams and with the cortical shell by about double number of equal radial bars. All beams cylindrical and not continued among shells.

Material. Numerous specimens in the Middle Miocene (late Badenian) Radiolarian Shale Formation from Subcarpathians and Getic Depression of Romania.

Holotype. Figure 10a, coll. MGL 103564.

Dimensions. Diameter of microsphere $23 \mu \mathrm{m}$, of external medullary shell $70 \mu \mathrm{m}$, of cortical shell $150-190 \mu \mathrm{m}$.

Etymology. The species is dedicated to the geologist Grigore Popescu who defined for the first time the Radiolarian Shale Formation in the Miocene of Subcarpathian area.

Remarks. This species differs from the specimen illustrated as Excentrodiscus sp. in Dumitrică 1978 (pl. 4, figs. 56 ) in having a smaller number of pores and thicker cortical shell in mature stage, but resembles the one illustrated in De Wever et al (2001) although both are from the same formation. Specimens assignable to this new species have been illustrated by Kamikuri (2010) from late Neogene of middle to high latitude of North Pacific and assigned to Excentrodiscus japonicus (Nakaseko \& Nishimura, 1974). However, Nakaseko and Nishimura's species, originally determined as Prunulum japonicum, differs from Excentrodiscus grigorei nov. sp. by having many 54 more and much smaller pores. So, the two species are not synonym.

Range and occurrence. Middle Miocene (late Badenian), Radiolarian Shale Formation, Subcarpathians and Getic Depression, Romania.

Genus Excentrococcus Dumitrică, 1978

Type species. Excentrococcus annulatus Dumitrică, 1978. Diagnosis. Test flat, disc-shaped with an eccentric microsphere in an outer medullary shell. Medullary shell surrounded by 2-6 circular or oval latticed rings.

Remarks. This genus resembles the genus Flustrella Ehrenberg from which it differs in having the microsphere eccentric in the second shell.

Range. Middle Miocene to Recent so far known.

\section{Excentrococcus annulatus Dumitrică, 1978.}

Figures 8a, 8c

1972 Phacodiscidae? gen. indet. Petrushevskaya \& Kozlova, pl. 19, fig. 15.

1973 Xiphospira sp. cf. X. circularis Kling, p. 635, pl. 7, fig. 16, non 11-15, 17.

1978 Excentrococcus annulatus Dumitrică, p. 238, pl. 2, fig. 12; pl. 5, figs. 19, 23.

1992 Excentrococcus annulatus Dumitrică - Sugiyama \& Furutani, p. 202, pl. 12, fig. 4; ?pl. 16, fig. 4.

1992 Excentrosphaerella sphaeroconcha Dumitrică Sugiyama \& Furutani, p. 202, pl. 12, figs. 1, 2; ?pl. 16, fig. 3 .

1999 Perichlamidium sp. cf. Ommatodiscus perichlamydium Dreyer - Tan \& Chen, p. 209, fig. 5-122.

2004 Excentrococcus annulatus Dumitrică. - Kamikuri et al., pl. 8, fig. 10 .

Description. Test flat consisting of a double medullary shell with a very small eccentric microsphere; this structure surrounded by two to maximum six latticed circular or oval rings. When number of rings is maximum, shell is oval with an end open and external outermost rings are thinner, irregular and with smaller pores.

Dimensions. Maximum length of shell around 150-160 $\mu \mathrm{m}$.

Remarks. The species is very variable in shape and number of rings, probably depending on the biological age of specimens and environment. The common number of shells is six and maximum eight, as the specimen illustrated in Fig. 8a of the present paper or in Tan \& Chen (1999) and Kamikuri et al. (2004). Up to the level of four shells the rings have large pores. The fifth and sixth rings are less regular and their pores are smaller, and the outermost seems to become slightly spongy. As the species is disc-shaped and the outer medullary shell is partly outside (fig. 8c), the maximum thickness of the disc is as great as the diameter of this shell. As a rule, the largest or the most complete specimens are oval and have a pylome marked by an indentation at one end (Fig. 8a in the present paper and in Kamikuri et al., 2004) or by an open ring (Tan \& Chen, 1999). This pylome or indentation is situated on the direction in which the microsphere is most close to outer medullary shell. This signifies that there is a correlation between the position of the microsphere and the pylome.

Range and occurrence. Middle Miocene to Recent, cosmopolitan. 

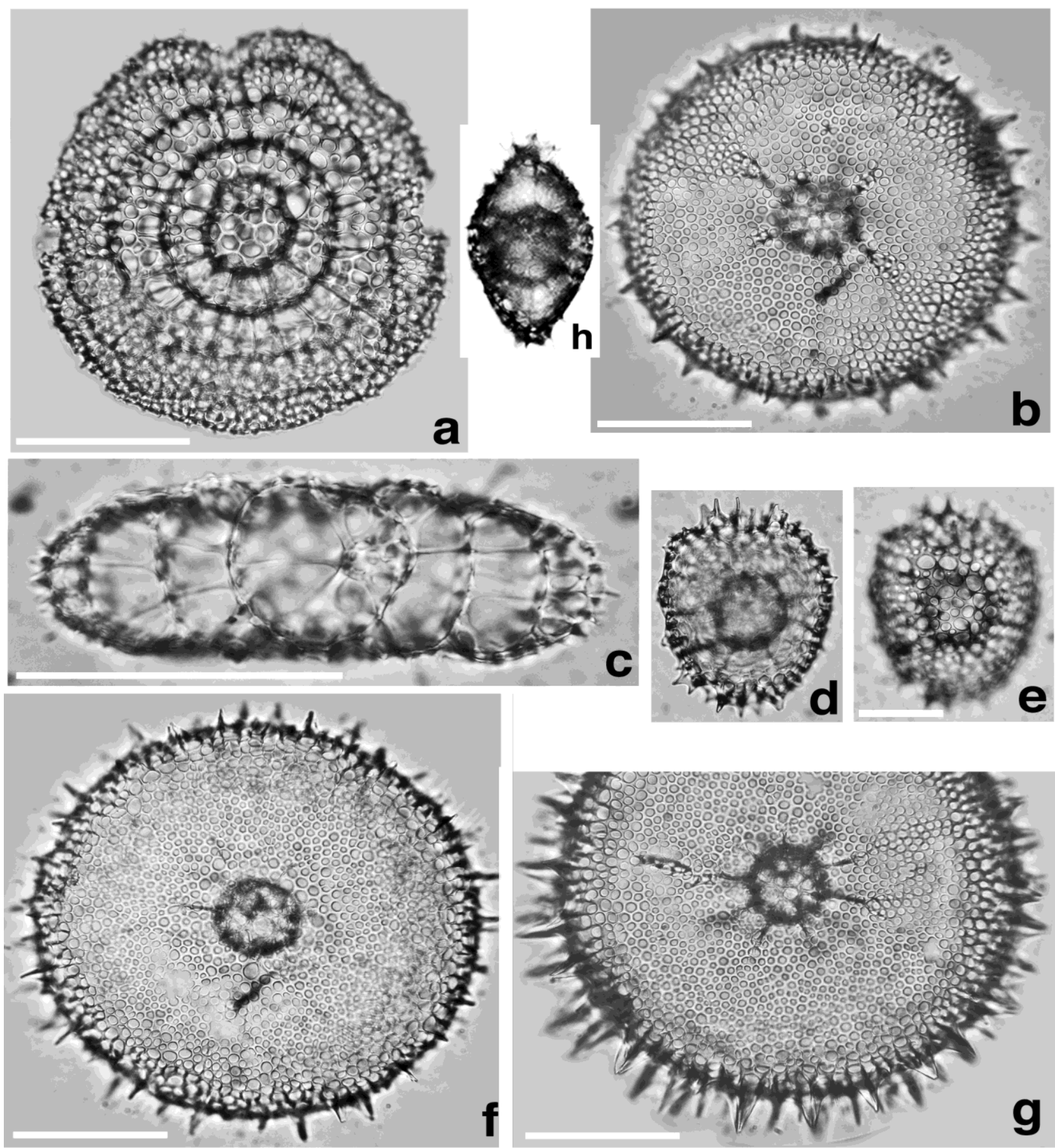

Fig. 8 a, c - Excentrococcus annulatus Dumitrică; a - mature specimen, face view, DSDP 21-205-7-1, 70-72 cm, scale bar 100 $\mu \mathrm{m} ; \mathbf{c}$ - other specimen, transversal section along the longitudinal axis showing the eccentric microsphere, DSDP 21-206-29CC, scale bar $=100 \mu \mathrm{m}$. b, f, $\mathbf{g}$ - Heliodiscus riedeli nov. sp., PROA 96P. d, e, $\mathbf{h}-$ Heliodiscus bipolaris nov. sp. focused at centre, on surface, and in lateral view, respectively, scale bar $=50 \mu \mathrm{m}$, DSDP 21-206-29CC.

Genus Excentrosphaerella Dumitrică, 1978

Type species. Excentrosphaerella sphaeroconcha Dumitrică, 1978

Range and occurrence. Santonian-Campanian of Kamchatka? (Vishnevskaya, 2006) to middle Miocene (late Badenian), Radiolarian Shale Formation of Romanian Subcarpathians and Getic Depression).

Excentrosphaerella sphaeroconcha Dumitrică, 1978
Figures 10e-h; 11a-b

?1887 Actinomma (Actinommura) capillaceum Haeckel, p. 255 , p.. 29, fig. 6 .

1978 Excentrosphaerella sphaeroconcha Dumitrică, p. 238, pl. 5, figs. 17, 18, 22.

non 1992 Excentrosphaerella sphaeroconcha Dumitrică Sugiyama \& Furutani, p. 202, pl. 12, figs. 1, 2; ?pl. 16, fig. 3 . 

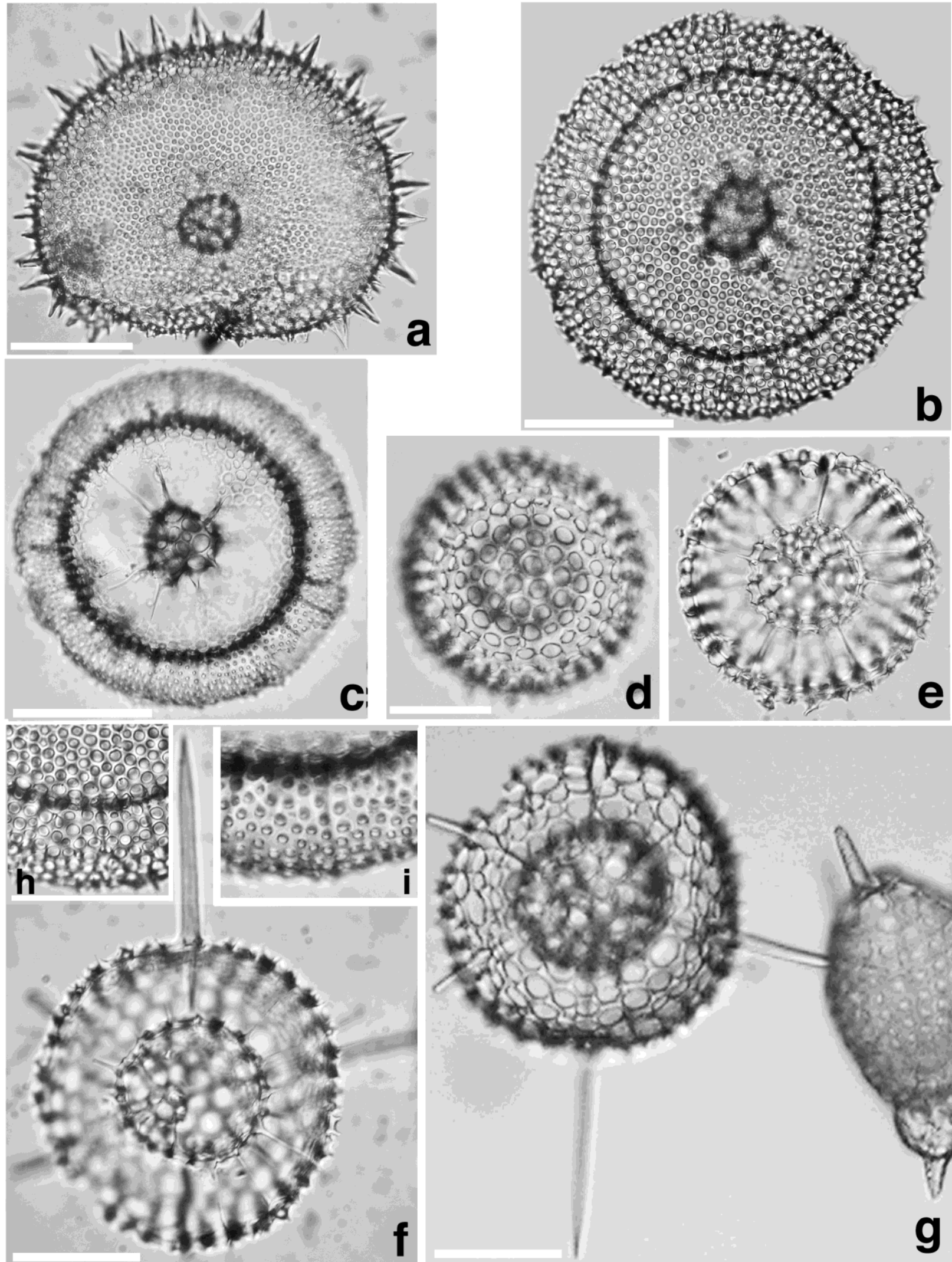

Fig. 9 a - Heliodiscus riedeli nov. sp, specimen broken and repaired during life, PROA 96P. b - Helioferrusa hollandei nov. gen., nov. sp., holotype, scale bar $=100 \mu \mathrm{m} ; \mathbf{h}$ - portion of shell more magnified, PROA 96P; $\mathbf{c}-$ Helioferrusa hollandei nov. sp., paratype, scale bar $=100 \mu \mathrm{m} ; \mathbf{i}-$ portion of shell more magnified, DSDP 21-205-7-1, 70-72 cm. d, e - Excentrodiscus dodo nov. sp., holotype, focused on surface of cortical shell and half sectioned showing the outer medullary shell and the eccentric microsphere, DODO $123 \mathrm{D}$, scale bar $=50 \mu \mathrm{m}$. f, $\mathbf{g}$ - Excentrodiscus kamikurii nov. sp., partly sectioned showing the outer medullary shell, the eccentric microsphere, and the cortical shell, respectively; $\mathbf{g}$ - same, overturned showing the cortical shell, a spine is blocked in the pore of a nassellarian Sethochytris sp., DODO 123D, scale bar $=50 \mu \mathrm{m}$. 


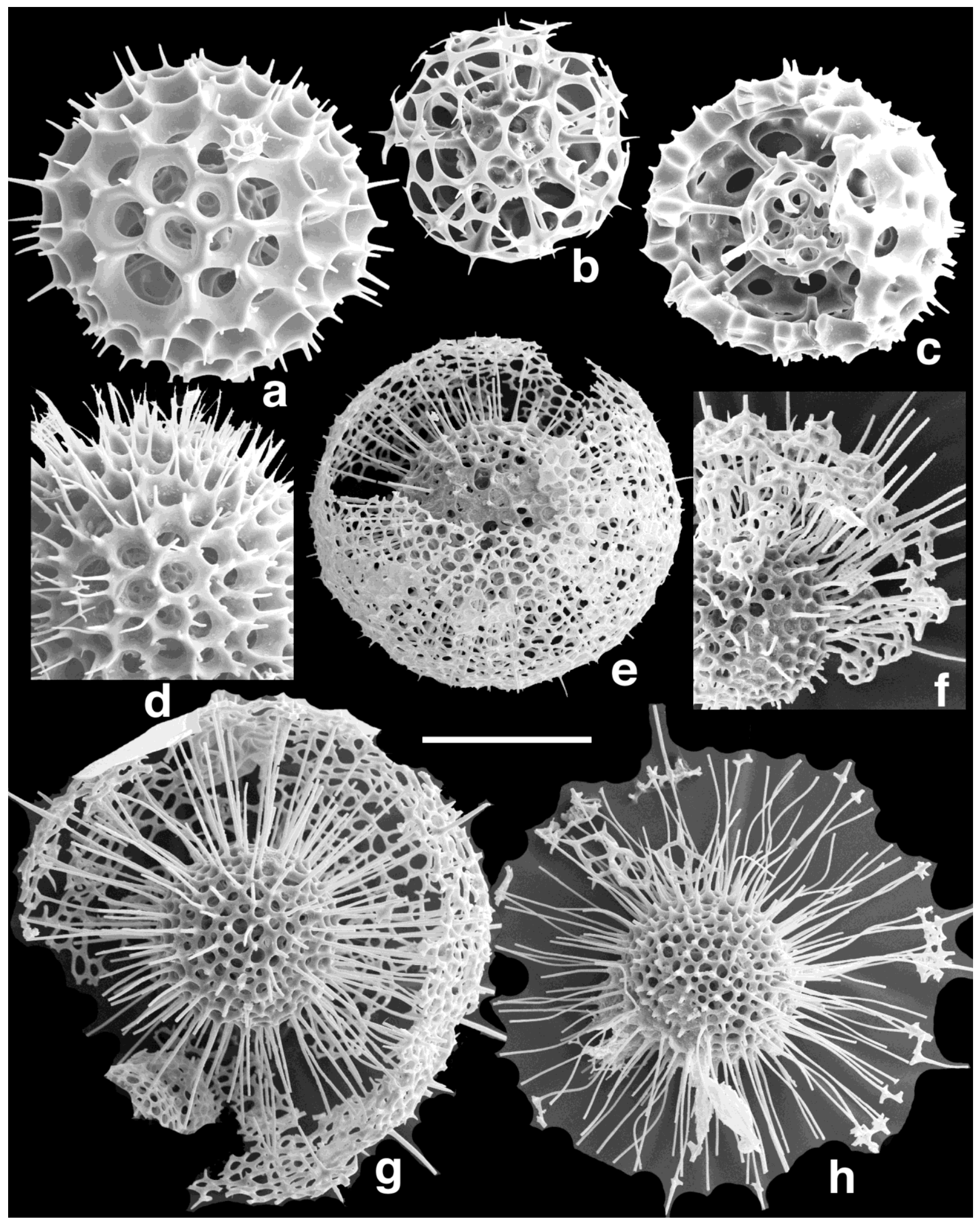

Fig. 10 a-d. Excentrodiscus grigorei nov. sp.: a - holotype; $\mathbf{b}$ - young specimen with incompletely built cortical shell; $\mathbf{c}-$ mature specimen with cortical and outer medullary shells partly broken off showing inside the eccentric microsphere in oblique antapical position. e-h. Excentrosphaerella sphaeroconcha Dumitrică: e - mature specimen with cortical shell partly broken off showing details of its wall, of the third shell and of the numerous rays connecting the two shells; $\mathbf{f}, \mathbf{h}-$ young specimens with tuberculate and normal cortical shell, respectively. Scale bar of all specimens $=100 \mu \mathrm{m}$, all specimens from sample 1315, Radiolarian Shale Formation, Păușești Otăsău, Romania. 
Description. Microsphere very small and eccentric in a spherical or slightly prunoid outer medullary shell. Outer shell spherical, rather thin-walled with polygonal to circular or subcircular pores and thin intervening bars. Cortical shell spherical, rather thin-walled and with numerous irregular polygonal pores and thin intervening bars. All shells interconnected by numerous filamentous beams, their number increasing with each shell so that between the third and the fourth shell their number is about one hundred or more. These beams are prolonged outside cortical shell into short and thin conical spines.

Dimensions. Diameter of microsphere 13-14 $\mu \mathrm{m}$, of outer medullary shell $55-65 \mu \mathrm{m}$, of third shell 117-123 $\mu \mathrm{m}$, of cortical shell 217-280 $\mu \mathrm{m}$.

Remarks. The species illustrated by Sugiyama \& Furutani (1992) as Excentrosphaerella sphaeroconcha does not belong to this species but to Excentrococcus annulatus Dumitrică. E. sphaeroconcha has all shells sphaerical whereas the specimen illustrated by them is flat as Excentrococcus and the shells outside outer medullary shell are ring-shaped. The best argument for this assignment is that the second, the third and the fourth shells are all focussed on their surface, whereas if they were spherical only the second shell could show its pores, the other two would have shown an optical section of their wall (see Dumitrică 1978, pl. 5, figs. 17, 18, 22, and Fig. 11 of the medullary shell with large circular or oval pores. Third

present paper). The number of shells is not an argument to assign this specimen to Excentrosphaerella, important is that they be spherical.

Excentrosphaerella sphaeroconcha Dumitrică, as illustrated by SEM (Fig. 10f, g), resembles very much the type species of the subgenus Actinomma (Actinommura) capillaceum Haeckel (1887, p. 255, pl. 29, fig. 6): the same morphology of the last two shells with polygonal pores, thin intervening bars, the same type of connection between them by numerous (around 100) filamentous beams that extend outside cortical shell into thin spines, and also rather similar diameters. The only difference is inside the middle shell. Haeckel illustrated a single microsphere, whereas the middle Miocene species from Romania has clearly a double medullary shell with an eccentric microsphere (Fig. 11b). The problem is: are the two species synonyms? If we agree that they are, we should consider that the specimen illustrated by Haeckel had also an eccentric microsphere inside the shell he considered as being microsphere but he could not see it. However, in the entire specimen illustrated by Dumitrică (1978, pl. 5, fig. 17) the eccentric microsphere seems to be rather well visible as a black area. There is also another argument in favour of the synonymy of the two species: the size of the microsphere. Haeckel considered the diameter of his so-called microsphere as being of $0.4 \mathrm{~mm}$.

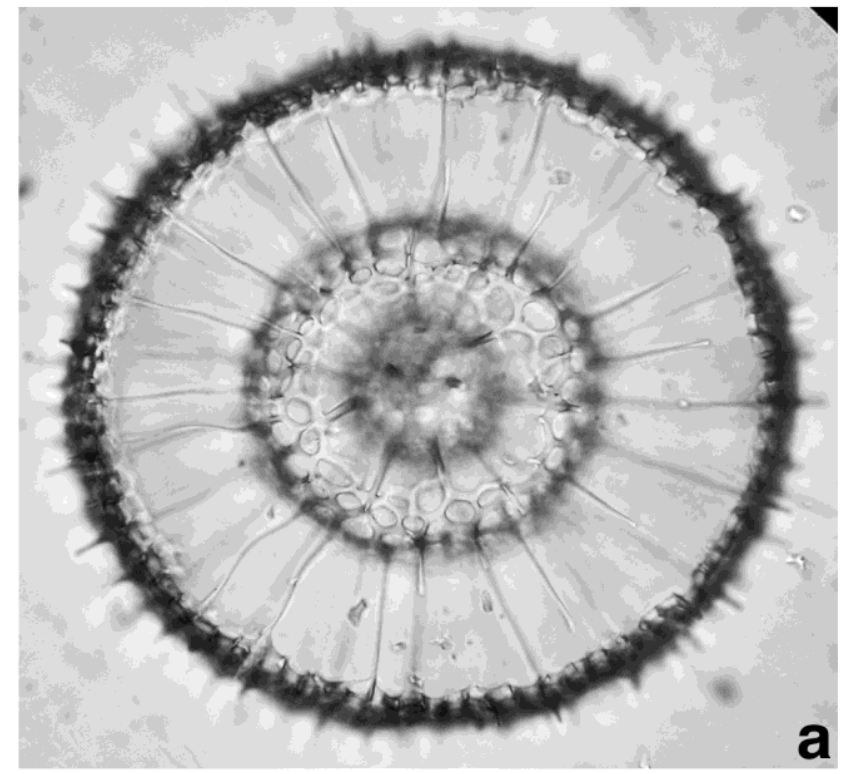

Fig. 11 a, b. Excentrosphaerella sphaeroconcha Dumitrică, partly sectioned specimen showing the inner shells, focused on the third and second shell, respectively, sample 1315, Radiolarian Shale Formation, Păușești Otăsău, Romania, scale bar = $100 \mu \mathrm{m}$.

The microspheric diameter of the Heliodiscidae is usually 13-20 $\mu \mathrm{m}$ but usually closer to the smallest value than to the greatest one. In this case, the diameter of the "microsphere" of $A$. capillaceum $(0.4 \mathrm{~mm})$ is more than double the measured diameter of the microsphere of the Heliodiscidae and closer to the diameter of the outer medullary shell of the members of this family. The conclusion would be that the two species could be synonym and that the genus Excentrosphaerella could be a junior synonym of Actinommura Haeckel 1887. However, since a certain doubt of this synonymy exists, especially also because in the same subgenus Haeckel included Actinommura arcadophorum Haeckel 1887, which is an entactinarian of the genus Rhizosphaera Haeckel (Dumitrică, 2017) I prefer to consider the two genera valid and belonging to 2 independent families.

Range and occurrence. Rather frequent at some levels of the Radiolarian Shale Formation in both Subcarpathians and Getic Depressions, late middle Miocene (late Badenian), Romania. 


\section{CONCLUSION}

During the Cenozoic, eccentric microsphere occurred in at least 3 not closely related spumellarian Radiolaria families: Suttoniidae, Patulibracchiidae and Heliodiscidae, and are rather sparse in radiolarian assemblages. The members of the first family have in common not only an eccentric microsphere but also a diploconchal initial structure consisting of the eccentric microsphere to which is attached a crescent shape deuteroconcha on its antapical part.

During evolution, the deuteroconcha of Homunculodiscus nov. gen. showed a trend towards unification of the initially 3-4 very small chambers, characteristic of the earliest Paleocene species $H$. nascens nov. sp, into two spherical larger chambers (H. trilobatus nov. sp.) or a small single crescent shaped chamber $(H$. cauleti nov. sp.), in the youngest levels of the earky Paleocene, to finally a chamber larger than the microsphere $(H$. tainemplecta (Caulet)) in the Eocene. At the same time the inner structure tended to form arches and finally circles or ellipses around the diploconchal structure.

In the genus Suttonium Schaaf, that probably originated in the genus Homunculodiscus by developing 3 primary beams, during evolution the microsphere tended to get out of deuteroconcha and the latter from the regularly triradial cortical shell, the final shape of shell resembling the letter $\mathrm{T}$.

The genus Parasuttonium nov. gen. has a morphology intermediate between that of Homunculodiscus and that of Suttonium, and it should also contain several older species proving this interpretation.

The genus Trimanicula Dumitrică, among the Patulibracchiidae, tended, on the contrary, to have all rays under $120^{\circ}$ from the initially $\mathrm{T}$-shaped position between the earliest Paleocene T. penultima Dumitrică and the early Oligocene to early Pliocene $T$. centrospina Dumitrică.

The genus Cryptomanicula nov. gen., is very strange for the Patulibracchiidae because it has no outer arms but a perfect disc-shaped skeleton, which is an exception in this family.

The Neogene genus Heliodiscus Haeckel arose probably by a horizontal gene transfer between Excentrodiscus Hollande \& Enjumet and Phacodiscus Haeckel or other phacodiscids during the early Miocene, from the latter inheriting the lenticular shape of the cortical shell.

The genus Helioferrusa nov. gen., originated in Heliodiscus, quite probably $H$. riedeli nov. sp., by appearance of a peripheral ring instead of peripheral spines.

\section{ACKNOWLEDGEMENTS}

I am very much obliged to Prof. Noritoshi Suzuki, Graduate School of Science, Tohoku University, Sendai, Japan, and to Dr. Johan Renaudie, Museum für Naturkunde, Berlin, for their kindness to review the first draft of the manuscript and for many critical remarks and proposals to improve it. Their reviews are very much appreciated.

\section{REFERENCES}

Burns, R.E., Andrews, J.E., van der Lingen, G.J., Churkin, M. Jr., Galehouse, J.S., Packham, G.H., Davies, T.A., Kennett J.P., Dumitrica, P., Edwards, A.R., von Herzen, R.P., 1973. Sites 205-208. Initial Reports of the Deep Sea Drilling Project, 21: 57-331, Washington (U.S. Government Printing Office).

Campbell, A.S., 1954. Radiolaria. In: Treatise on Invertebrate Paleontology (R.C. Moore ed.). University Kansas Press and Geological Society of America), Pt. D., Protista 3: 11-163.

Caulet, J.-P., 1991. Radiolarians from the Kerguelen Plateau, Leg 119. In: Barron, J., Larsen, B., et al., Proceedings of the Ocean Drilling Program, Scientific Results, 119: 513-546.

Cheng, Y.N., Yeh, K.Y., 1989. Radiolaria in surface sediments from west central Pacific near Taiwan. Bulletin of National Museum of Natural Science, 1: 177211.

De Wever, P., Dumitrică, P., Caulet, J.P., Nigrini, C., Caridroit, M. 2001. Radiolarians in the sedimentary record. Gordon and Breach Science Publishers, Amsterdam, $533 \mathrm{pp}$.

Dumitrică, P., 1965. Sur la présence de Phéodaires fossiles dans le Tortonien des Subcarpathes roumaines. Comptes Rendu Academie de Science Paris, 260: 250-253.

Dumitrică, P., 1978. Badenian Radiolaria from Central Paratethys. In: E. Brestenská (ed.) Chronostratigraphie und Neostratotypen. Miozän der Zentralen Paratethys, Bd. 6, Miozän M4 - Badenien: 231-261, VEDA Bratislava.

Dumitrică, P., 1983a. Systematics and evolution of the genus Suttonium Schaff (Radiolaria). Revue de micropaléontologie, 26, (1): 36-47, pls. 1-3.

Dumitrică, P., 1983b. Evolution of Mesozoic and Cenozoic Centrocubidae (Radiolaria). Revue de Micropaléontologie, 25 (4): 221-230.

Dumitrică, P., 1984. Systematics of sphaerellarian radiolarians. In: Morphology, Ecology and Evolution of Radiolarians: EURORAD-IV, Nauka, Leningrad: 91102 (in Russian).

Dumitrică, P., 1988. New families and subfaminies of Pyloniacea (Radiolaria). Revue de Micropaléontologie, 31 (3): 178-195.

Dumitrică, P., 1989. Internal skeletal structures of the superfamily Pyloniacea (Radiolaria), a basis of a new systematics. Revista española de micropaleontología, 21 (2): 207-264, pls. 1-15, Madrid.

Dumitrică, P., 1991. Cenozoic Pyloniacea (Radiolaria) with a five-gated microsphere. Revue de micropaléontologie, 34 (1): 35-56.

Dumitrică, P., 2016. Middle Miocene (late Badenian) Phaeodaria from Romania. Acta Palaeontologica Romaniae, 12 (2): 3-20.

Dumitrică, P., 2017. Contribution to the knowledge of the Entactinaria radiolarian family Rhizosphaeridae Haeckel and description of some new genera and species. Revue de micropaleontologie, 60: 469-491.

Ehrenberg, C.G., 1838. Über die Bildung der Kreidefelsen und des Kreidemergels durch unsichtbare Organismen. Abhandlungen der königlichen Akademie der Wissenschaften zu Berlin, Jahrg. 1838: 59-147.

Ehrenberg, C.G., 1854. Mikrogeologie. Leipzig. xxviii+374 pp., Atlas, 31 pp. +41 pls.

Funakawa, S., Nishi, H., 2005. Late middle Eocene to late Oligocene radiolarian biostratigraphy in the 
Southern Ocean (Maud Rise, ODP Leg 113, Site 689). Marine Micropaleontology 54: 213-247.

Funakawa, S., Nishi, H., Moore, T.C., Nigrini, C.A., 2006. Data report: Late Eocene-early Oligocene radiolarians, ODP Leg 199 Holes 1218A,1219A, and 1220A, central Pacific. in: Wilson, P.A., Lyle, M., and Firth, J.V. (eds.), Proceeding of the Ocean Drilling Program, Scientific Results, 199, 1-74.

Haeckel, E., 1862. Die Radiolarien (Rhizopoda Radiaria). Eine Monographie. (Reimer, Berlin) xiv+572 pp, 35 pls.

Haeckel, E., 1881. Entwurf eines Radiolarien - Systems auf Grund von Studien der Challenger-Radiolarien. Jenaische Zeitschrift Naturwissenschaften, 15 (n. ser., 8), no. 3: 418-472.

Haeckel, E., 1887. Report on the Radiolaria collected by H.M.S. Challenger during the years 1873-76. Report on Scientific Results of the Voyage of H.M.S. Challenger during the years 1873-76, Edinburgh, Zool. 18, 1803 pp., 140 pls.

Hollande, A., Enjumet, M., 1960. Cytologie, évolution et systématique des Sphaeroïdés (Radiolaires). Archives du Muséum National d'Histoire Naturelle, Paris, $7^{\mathrm{e}}$ Série, vol. 7: 1-134, 64 pls.

Hollis, Ch.J., 1997. Cretaceous-Paleocene Radiolaria from eastern Marlborough, New Zealand. Institute of Geological \& Nuclear Sciences monograph, 17 (New Zealand Geological Survey paleontological bulletin, 73, 152 pp.).

Kamikuri, Sh., 2010. New late Neogene radiolarian species from the middle to high latitudes of the North Pacific. Revue de micropaléontologie, 53: 85-106.

Kamikuri, Sh., 2015. Radiolarian assemblages during the middle-late Eocene transition at Site 1052, ODP Leg 171B, Blake Nose, western North Atlantic Ocean. News of Osaka Micropaleontologists (NOM), Special vol. 15: 139-167.

Kamikuri, Sh., Nishi, H., Motoyama, I., Saito, S., 2004. Middle Miocene to Pleistocene radiolarian biostratigraphyin the Northwest Pacific Ocean, ODP Leg 186. The Island Arc 13: 191-226.

Kawakami, Sh., 2001. Upper Miocene radiolarians from the Nishizaki Formation and Ishido Group in the southern part of Boso Peninsula, Japan, and their geological significance. News of Osaka Micropaleontologists (NOM), Special vol. 12: 343-358.

Kling, S.A., 1973. Radiolaria from the eastern north Pacific Deep Sea Drilling Project, Leg 18. Initial Reports of the Deep Sea Drilling Project, 18: 617-671. Washington (U.S. Government Printing Office).

Müller, J., 1858. Über die Thalassicollen, Polycystinen und Acanthometren des Mittelmeeres. Abhandlungen der königlichen Akademie der Wissenschaften $\mathrm{zu}$ Berlin. Jahrg. 1858: 1-62.

Nakaseko, K., Nishimura, A., 1974. Miocene radiolarian fossils of the Oki Islands in Shimane Prefecture, Japan. Osaka University, Science Reports, 23 (1-2): 4573.

Nigrini, C., 1967. Radiolaria in pelagic sediments from the Indian and Atlantic oceans. Bulletin of the Scripps Institution of Oceanography, University of California, San Diego, La Jolla, California, vol. 11, 125 pp.
Nishimura, A., 2001. Paleocene Radiolarians from DSDP Leg 43, Site 384 in the Northwest Atlantic. News of Osaka Micropaleontologists (NOM), Special vol. 12: 293-320.

Pessagno, E.A., Jr., 1971. Jurassic and Cretaceous Hagiastridae from the Blake-Bahama Basin (Site 5A, Joides Leg I) and the Great Valley Sequence, California Coast Ranges. Bulletin American Paleontology 60, no. 264: 5-83, pls. 1-19.

Petrushevskaya, M.G., 1987. Possible development of phacoid test in Radiolaria Sphaerellaria. Zoologicheskii Zhurnal, 66 (10): 1445-1453, Moskow.

Petrushevskaya, M.G., Kozlova, G.E., 1972. Radiolaria: Leg 14, Deep Sea Drilling Project. In: Hayes, D.E., Pimm, D.E., et al., Initial Reports of the Deep Sea Drilling Project, 14: 495-648. Washington (U.S. Government Printing Office).

Riedel, W.R., 1967. Subclass Radiolaria. In: Harland, W.B., Holland, C.H., House, M.R., Hughes, N.F., Reynolds, A.B., Rudwick, M.J.S., Satterthwaite, G.E., Tarlo, L.B.H., Willey, E.C. (Eds.). The fossil record. The Geological Society of London: 291-298.

Riedel, W.R., 1971. The occurrence of pre-Quaternary Radiolaria in dee-sea sediments. The Micropaleontology of Oceans. In: B.M. Funnel \& W.R. Riedel (eds.), Cambridge, UK, Cambridge University Press: 567594.

Schaaf, A., 1976. Suttonium praedicator nov. gen., nov. sp. (Radiolaria, Nassellaria) et la famille des Suttonidae nov. fam. Geobios, 9 (6): 789-792, pl. 1.

Sugiyama, K., Furutani, H., 1992. Middle Miocene radiolarians from the Oidawara Formation, Mizunami Group. Gifu Prefecture, central Japan. Bulletin of the Mizunami Fossil Museum, 19: 199-213.

Sutton, H.J., 1896. Radiolaria; a new species from Barbados. American Monthly Microscopical Journal, 17 (2): 58-61.

Tan, Zh., Chen, M., 1999. Offshore Radiolaria in China. Science Press, Beijing, China, 404 pp., 14 pls., 390 text-figs., 9 Tabs. (in Chinese with English abstract).

Tanimura, Y., Aita, Y. (eds.), 2009. Joint Haeckel and Ehrenberd Project: Reexamination of the Haeckel and Ehrenberg Microfossil Collections as a Historical and Scientific Legacy. National Museum of Nature and Science, Tokyo, sept. 2009: 1-106.

Vishnevskaya, V.S., 2006. New species of the family Heliodiscidae Haeckel (Radiolaria). Paleontological Journal, 40 (2): 134-142, Pleiades Publishing, Inc.

Vishnevskaya, V.S., Bernard, V.V., 2004. Representatives of the family Heliodiscidae Haeckel (Radiolaria) as records of the paleoenvironmental evolution. $4^{\text {th }}$ International Congress "Environmental Micropaleontology, Microbiology and Meiobenthology", Isparta, Turkey. September 13-18, 2004, 2 pp.

Vishnevskaya, V.S., Dumitrică, P., 2003. Excentrosphaerella kamchatica nov. sp, the oldest known heliodiscid radiolarians in the Upper Cretaceous of Kamchatka. Abstracts INTERRAD X Lausanne, p. 113.

Yeh, K.Y., Cheng, Y.N., 1990. Radiolaria in surface sediments from marginal basin of southwest Taiwan. Bulletin of National Museum of Natural Science, 2: 65-87. 